\title{
Sustainability assessment of the German energy transition
}

\author{
Christine Rösch", Klaus-Rainer Bräutigam, Jürgen Kopfmüller, Volker Stelzer and Annika Fricke
}

\begin{abstract}
Background: The goal of the energy transition in Germany is to achieve a sustainable supply of energy. Providing advice for decision-makers to either continue the current transition pathway or implement strategic adjustments requires a comprehensive assessment tool. The authors have developed a Sustainability Indicator System (SIS) consisting of 45 indicators to assess if policy measures implemented so far by the Federal Government are appropriate and sufficient to achieve the energy policy targets and, furthermore, the sustainability targets defined for the German energy system.

Methods: The assessment is carried out applying the SIS. For each indicator, a linear projection was calculated, based on the past 5 years for which data were available, assuming that this trend will continue in a linear way until 2020. Then, the projected value for 2020 resulting from the trend was compared to the political or defined target for 2020. The assessment was based on distance-to-target considerations, i.e. to which degree the set, proposed or desirable target will be met within the framework of the existing energy policy. The results are illustrated using a traffic light colour code. Indicators with less than 5 years of data available were given a white traffic light since no assessment was possible.
\end{abstract}

Results: A profound view on eight selected sustainability indicators that are not already part of the German monitoring process 'Energy of the Future' and a comprehensive overview on the sustainability assessment of the German energy system are presented. The results show that $24 \%$ of the assessed indicators are rated with a green, $7 \%$ with a yellow, $45 \%$ with a red and $24 \%$ with a white traffic light. This means that it cannot be expected that the sustainability targets defined for the German energy system will be achieved by 2020 without substantial modifications of political strategies and measures implemented so far.

Conclusions: The developed SIS is a comprehensive decision support and navigation tool with respect to long-term governance of the German energy transition. It aims to assess and monitor the overall sustainability performance of the energy system, to identify unsustainable energy strategies and measures as well as trade-offs and to evaluate the achievements or failures of policies regarding the energy transition. It can also be adapted to assess the sustainability of the energy systems in other European countries.

Keywords: Sustainability, Assessment, Indicators, Energy system, Energy transition

\section{Background}

The transformation of the German energy system is considered as key element to achieve sustainability at the national scale. This is according to the Brundtland report claiming that 'a safe and sustainable energy pathway is crucial to sustainable development' [1] and particularly to the latest and most relevant framework in this respect, the 17 sustainable development goals (SDGs) defined by the United

\footnotetext{
* Correspondence: christine.roesch@kit.edu

Institute for Technology Assessment and Systems Analysis (ITAS), Karlsruhe Institute of Technology (KIT), Karlstraße 11, 76133 Karlsruhe, Germany
}

Nations [2]. Goal 7 refers to the energy topic by demanding universal access to affordable, reliable and modern energy services for everybody. This includes, among others, a substantial increase of the renewable energy share in the global energy mix, doubling global energy efficiency rates, as well as according infrastructure expansion and modernization and technology upgrades for supplying sustainable energy services. Given that, it is obvious that planning and design of the transformation process requires a holistic understanding of sustainable development (SD), including environmental, economic, social and institutional issues, and a 
deliberate monitoring and evaluation of possible implications of possible pathways to achieve the goals.

While the goal of a nuclear-free energy supply in Germany is widely shared, the transition pathway and the required specifications of the future energy system are lively and controversially debated in science, politics and society. The debate focuses on strategies and measures towards a more sustainable energy system including a secure, environmental-friendly and economically affordable energy supply and a high public acceptance. In particular, the design of transition measures that suitably consider the socio-technical characteristics and interfaces of the energy system, and their several interdependencies, are debated. The question, to which degree steadily increasing electricity prices for private customers due to the National Renewable Energy Law (EEG) lead to 'energy poverty', is one example for this. Thus, one essential precondition for both, a coherent energy transition policy, and a sufficient support of a critical public is that the consequences of political decisions for a complex socio-technical energy system are taken into account appropriately.

The monitoring process 'Energy of the Future' established by the Federal Government continuously reviews if the current trend is on track to attain the goals and targets set out in the German Energy Concept, and if additional measures should be implemented. In this process, indicators are used to take annual stock of the progress made in achieving the quantitative targets [3-7]. The strategies and measures taken for the energy transition, however, have impacts also on other sustainability issues and, thus, can trigger interactions and trade-offs with respect to and between sustainability criteria that are not included in the monitoring system. Therefore, a more comprehensive set of sustainability criteria is needed. To give an example: While higher shares of renewable energy sources are necessary to achieve a carbon-free energy system, the construction, operation and disposal of renewable energy technologies require a substantial amount of resources (e.g. land, water, nutrients, rare materials) including possible strong impacts on natural and social systems. In particular, social aspects, such as fair social distribution of benefits and burdens due to the energy transition, or participation of citizens in relevant decisions within the transformation process are to a large extent missing in the German monitoring process. To fill this knowledge gap, the authors have developed a comprehensive Sustainability Indicator System (SIS) within the Helmholtz Alliance project 'Energy-Trans' to improve the assessment of the energy transition process in Germany [8]. In this paper, selected results of this assessment are presented and discussed.

\section{Methods}

The assessment of the sustainability performance of the German energy system was carried out using the SIS, which was developed based on the integrative concept of sustainable development. More information about this concept and how the indicators have been selected can be found in [8]. The SIS consists of 45 indicators (Table 1), including mainly objective indicators but also a few subjective, survey-based indicators (nos. 34, 35 and 36). The indicator assessment includes three methodological steps:

1. Collection, selection and analysis of facts and figures and preparation of data series

2. Definition of targets for each indicator for the years 2020, 2030 and 2050

3. Calculation of a trendline and assessment of the extrapolated values by the distance-to-target method

Sustainability indicator targets for 2020, 2030 and 2050

Since a distance-to-target (DTT) approach was applied in this project for the indicator-based assessment of the energy system and its transition, targets obviously have a key function. The targets defined are important reference lines for indicator values to be compared with. Strategically, they should allow for higher planning reliability of actors, in particular if targets are designed stepwise over time, and help decision-makers to design political measures. From the DTT approach, the necessity aroused to define targets for all indicators in the SIS. However, not for all of the defined indicators political justified and binding targets were available, since the indicators selected to cover the socio-technical interface of the energy system are rather new. Thus, political discussions and processes of target setting in these cases are still ongoing or even missing. Therefore, we have carried out a comprehensive and profound review of documents from policy consulting institutions, such as the German Advisory Council on Global Change, science, NGOs, unions and other stakeholders and the media as well as the target agreements of other comparable countries to identify and adopt appropriate proposals for binding or non-binding targets. The objective of that wide-ranging investigation was to define target values for all indicators of the SIS in a comprehensive and reliable way. As a result, the present work comprises a mixture of set, proposed or desirable targets with different degree of justification by politics and society: Some of them have been derived from policy-based targets in 2020, both binding and non-binding, some were adopted from political targets or good examples in other countries, some from policy consulting institutions, some from science and other targets have been abstracted from public debates. As described above, in the presented work targets were determined based on these different sources, for the years 2020, 2030 and 2050. Primarily, political targets were adopted if available, either at the national or at the international scale. To give examples: For the indicators 'primary energy use, 
Table 1 The Sustainability Indicator System [8]

\begin{tabular}{|c|}
\hline ecuring human existence \\
\hline 1. Energy-related emissions of particulate matter \\
\hline 2. Energy-related emissions of cadmium \\
\hline 3. Energy-related emissions of mercury \\
\hline 4. Energy import dependency \\
\hline $\begin{array}{l}\text { 5. Monthly energy expenditures of households with a monthly net } \\
\text { income less than } 1300 \text { Euros }\end{array}$ \\
\hline 6. SAIDI of electricity \\
\hline $\begin{array}{l}\text { 7. Relation of employees in the renewable energy sector to total } \\
\text { employees }\end{array}$ \\
\hline 8. Final energy consumption of private households per capita \\
\hline $\begin{array}{l}\text { 9. Relation of technician salary to manager salary at the big electricity } \\
\text { suppliers }\end{array}$ \\
\hline Maintaining society's productive potential \\
\hline 10. Share of renewable energy in gross final consumption of energy \\
\hline 11. Area under cultivation of energy crops \\
\hline 12. Unused renewable electricity due to management measures \\
\hline 13. Use of primary energy \\
\hline $\begin{array}{l}\text { 14. Specific final energy consumption of households for heating } \\
\text { (temperature-corrected) }\end{array}$ \\
\hline 15. Final energy consumption in the transport sector \\
\hline 16. Modal split in the transport sector \\
\hline 17. Number of electric vehicles \\
\hline 18. Final energy productivity of the German economy \\
\hline 19. Final energy productivity of the industry \\
\hline 20. Final energy productivity of trade, commerce and services \\
\hline 21. Energy-related greenhouse gas emissions \\
\hline 22. Energy-related emissions of acid-forming gases \\
\hline 23. Energy-related hazardous solid wastes \\
\hline $\begin{array}{l}\text { 24. Amount of high-level radioactive waste which has not been } \\
\text { transferred to a safe final disposal site }\end{array}$ \\
\hline 25. Installed capacity of renewable energy power plants \\
\hline 26. Number of university graduates in the field of energy sciences \\
\hline 27. Federal expenditures for energy research \\
\hline $\begin{array}{l}\text { 28. Number of German patents in the field of renewable energy and } \\
\text { energy efficiency }\end{array}$ \\
\hline $\begin{array}{l}\text { 29. Number of start-ups in the renewable energy and energy efficiency } \\
\text { sector }\end{array}$ \\
\hline 30. Added value creation from the renewable energy sector \\
\hline $\begin{array}{l}\text { 31. Added value creation from energy efficiency measures in } \\
\text { households }\end{array}$ \\
\hline Preserving society's options for development and action \\
\hline 32. Gender pay gap in the highest salary group in the energy sector \\
\hline $\begin{array}{l}\text { 33. Share of regulatory tools in the planning of power transmission } \\
\text { grids that fulfil regulatory requirements }\end{array}$ \\
\hline $\begin{array}{l}\text { 34. Share of tourists who perceive energy power technologies as } \\
\text { being disruptive in the vacation area }\end{array}$ \\
\hline 35. Acceptance of ren \\
\hline
\end{tabular}

Table 1 The Sustainability Indicator System [8] (Continued)

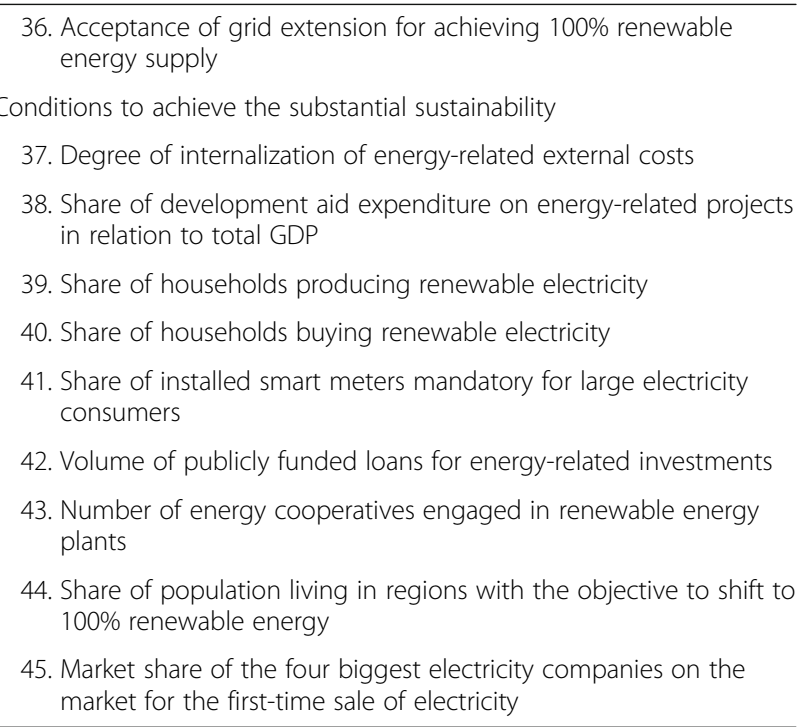

'energy-related greenhouse gas emissions' and 'number of electric vehicles', the political targets defined by the German government were used. For the indicator 'energyrelated emissions of mercury', the targets were taken from a United Nations protocol. In cases where targets exist only for 2050, the authors determined according values for 2020 and 2030, mainly based on a linear extrapolation. This was applied for the indicators 'emissions of particulate matter' and 'number of electric vehicles'.

Secondly, targets were adopted or derived from scientific or societal debates as, e.g. for the indicator 'relation of technician salary to manager salary in the big electricity suppliers' that refers to the Swiss debate, and for the indicator 'area under cultivation of energy crops', following recommendations of the German Advisory Council on Global Change. In addition, a cross-border look at other countries' best practices provided a source to derive targets. This was done for the indicators 'SAIDI for electricity' and 'federal expenditures for energy research'. The research spending in Germany in relation to its GDP and the research spending of the country with the highest value in this category (South Korea) are used as reference point for future expenditures.

For those indicators where no targets were available or discussed so far, conclusion by analogy was chosen as method, e.g. for the indicator 'final energy consumption of private households per capita' where the trend of the official target for national primary energy use was adopted. A similar procedure was applied for the indicator 'number of university graduates in energy sciences', assuming that this indicator develops proportionally to the volume of investments in Germany given in the DLR-Report [9], which provided the key basis for all model-based analyses in the project. For the indicator 'number of start-ups in renewable 
energy and energy efficiency sector', targets were defined in accordance with the indicators 'number of German patents in the field of renewable energy and energy efficiency' and 'federal expenditures for energy research'. Table 2 gives an overview on the targets defined for 2020, 2030 and 2050, briefly describes the origin of the targets and gives the main reference for the targets.

\section{Sustainability assessment based on the distance-to-target approach}

The performance of the sustainability indicators is assessed based on a combined linear extrapolation and distance-totarget approach used also in the German monitoring report 'Energy of the Future' [7]. Accordingly, a linear projection of the performance trend for each indicator was calculated based on the previous 5 years for which data were available, assuming that this trend will continue in a linear way until 2020. Then, this projected trend was compared to the targets for 2020, in order to assess to which degree the target will be met within the framework of the existing energy policy. The near-term target 2020 was chosen because here a linear projection is regarded as feasible since it can be assumed that the framework conditions influencing the energy system will remain relatively constant within this short time period and that effects of measures previously implemented will support the trend until 2020. For the period until 2050, however, it can be expected that due to the unpredictable nature of the complex and dynamic energy system, as well as changing political and institutional framework conditions, indicator performance trends will change accordingly and, thus, extrapolation is not a valid methodology any more. The traffic light symbol was used to visualize the assessment results (Fig. 1). The assessment includes the following steps:

- Defining a 'reference value' by calculating the average value of the last 5 years with data

- Calculation of a 'projected value' for 2020 by extrapolating the trendline, covering the past 5 years with data, until 2020

- Calculation of the relation between the necessary change (relation between 'reference value' and 'target value') and the expected change (relation between 'reference value' and 'projected value') according to the following formula:

$$
\left(1-\frac{1-\mathrm{PV}_{2020} / \mathrm{AV}_{5}}{1-\mathrm{TV}_{2020} / \mathrm{AV}_{5}}\right) \times 100 \%
$$

$\mathrm{PV}_{2020}$ projected value for 2020

$\mathrm{TV}_{2020}$ target value for 2020

$A V_{5}$ average value of the past 5 years with available data
The traffic light colours are defined as follows:

- Green traffic light: the deviation is $<10 \%$ or the projected value exceeds the target value.

- Yellow traffic light: the deviation is between 10 and $40 \%$.

- Red traffic light: the deviation is $>40 \%$ or the calculated trend goes in the 'wrong' direction (indicator value increase instead of decrease or decrease instead of increase).

- White traffic light: no distance-to-target evaluation can be carried out due to the lack of data series.

\section{Results}

The assessment results are part of elaborated fact sheets worked out for each of the 45 indicators composing the Sustainability Indicator System (SIS). These fact sheets include information on the justification and definition of the indicator, the unit, data sources, previous data trends, targets for 2020, 2030 and 2050, comments on data and targets, the result of the assessment applying the traffic colour code and the references used. In this paper, only some selected indicators are described in detail. The selection of the indicators is based on the innovativeness of the indicators for science and politics and if the indicators are 'new' and not (yet) used in the German monitoring process 'Energy of the Future'. The following indicators will be presented:

- Share of employees in the renewable energy sector in relation to total number of employees

- Monthly energy expenditure of households with a monthly net income less than 1300 Euros

- Area under cultivation of energy crops

- Number of start-ups in the renewable energy and energy efficiency sector

- Gender pay gap in the highest salary group in the energy sector

- Acceptance of renewable energies in the neighbourhood

- Degree of internalization of energy-related external costs

- Number of energy cooperatives engaged in renewable energy plants

An overview on the assessment results of all indicators comprised by the SIS is given afterwards in Fig. 10 including the figures showing the assessment results for the eight indicators mentioned above.

Share of employees in the renewable energy sector in relation to total number of employees

According to the UN Sustainable Development Goal 8, sustained, inclusive and sustainable economic growth 
Table 2 Sustainability Indicator System targets for 2020, 2030 and 2050

\begin{tabular}{|c|c|c|c|c|c|}
\hline & & \multicolumn{3}{|l|}{ Targets } & \multirow[t]{2}{*}{ Reference targets } \\
\hline & & 2020 & 2030 & 2050 & \\
\hline \multirow[t]{9}{*}{$\begin{array}{l}\text { Securing human } \\
\text { existence }\end{array}$} & $\begin{array}{l}\text { 1. Energy-related emissions of particulate } \\
\text { matter (kt) }\end{array}$ & 67.4 & 60.1 & 45.6 & $\begin{array}{l}\text { Target } 2020 \text { based on the amended protocol } \\
\text { of Gothenburg, assumptions for } 2030 \text { and } 2050\end{array}$ \\
\hline & 2. Energy-related emissions of cadmium ( $\mathrm{t}$ ) & 3.0 & 2.7 & 2.0 & \multirow{2}{*}{$\begin{array}{l}\text { Target } 2020 \text { developed by analogy based on } \\
\text { the amended protocol of Gothenburg, } \\
\text { assumptions for } 2030 \text { and } 2050 \text {. }\end{array}$} \\
\hline & 3. Energy-related emissions of mercury $(\mathrm{t})$ & 6.5 & 5.8 & 4.4 & \\
\hline & 4. Energy import dependency (\%) & 69 & 58 & 43 & Targets taken from [9]. \\
\hline & $\begin{array}{l}\text { 5. Monthly energy expenditures of households } \\
\text { with a monthly net income } \\
\text { less than } 1300 \text { Euros }\end{array}$ & 139 & 142 & 147 & $\begin{array}{l}\text { Targets developed by analogy based on [22] } \\
\text { and assumptions. }\end{array}$ \\
\hline & 6. SAIDI of electricity (min) & 12.5 & 10 & 10 & $\begin{array}{l}\text { Targets } 2030 \text { and } 2050 \text { developed by } \\
\text { analogy based on [64]. }\end{array}$ \\
\hline & $\begin{array}{l}\text { 7. Relation of employees in the renewable } \\
\text { energy sector to total employees (\%) }\end{array}$ & 0.94 & 0.93 & 1.19 & $\begin{array}{l}\text { Targets developed by analogy based on } \\
{[9,14] \text { and assumptions. }}\end{array}$ \\
\hline & $\begin{array}{l}\text { 8. Final energy consumption of private } \\
\text { households per capita (GJ/capita) }\end{array}$ & 29.3 & 24.7 & 17.6 & Targets developed by analogy based on [65]. \\
\hline & $\begin{array}{l}\text { 9. Relation of technician salary to manager } \\
\text { salary at the big electricity suppliers }\end{array}$ & $1: 12$ & $1: 12$ & $1: 12$ & Targets developed by analogy based on [66]. \\
\hline \multirow[t]{17}{*}{$\begin{array}{l}\text { Maintaining society's } \\
\text { productive potential }\end{array}$} & $\begin{array}{l}\text { 10. Share of renewable energy in gross final } \\
\text { consumption of energy }(\%)\end{array}$ & 23 & 36 & 60 & Targets taken from [9]. \\
\hline & $\begin{array}{l}\text { 11. Area under cultivation of energy crops } \\
\text { (mio. ha) }\end{array}$ & 2.0 & 1.9 & 1.6 & Targets developed by analogy based on [26]. \\
\hline & $\begin{array}{l}\text { 12. Unused renewable electricity due to } \\
\text { management measures (GWh) }\end{array}$ & 4047 & 2698 & 0 & $\begin{array}{l}\text { Target } 2050 \text { based on assumptions, linear } \\
\text { extrapolation for } 2030 \text { and } 2020 .\end{array}$ \\
\hline & 13. Use of primary energy (PJ/a) & 11,504 & 10,066 & 7190 & Targets taken from [65]. \\
\hline & $\begin{array}{l}\text { 14. Specific final energy consumption of } \\
\text { households for heating } \\
\text { (temperature-corrected) }\left(\mathrm{MJ} / \mathrm{m}^{2}\right)\end{array}$ & 435 & 367 & 230 & \multirow[t]{2}{*}{ Targets taken from [9]. } \\
\hline & $\begin{array}{l}\text { 15. Final energy consumption in the transport } \\
\text { sector (in PJ) }\end{array}$ & 2337 & 1973 & 1521 & \\
\hline & 16. Modal split in the transport sector (\%) & 20 & 20 & 20 & $\begin{array}{l}\text { Targets developed by analogy based on [9] } \\
\text { and own assumption. }\end{array}$ \\
\hline & 17. Number of electric vehicles (mio.) & 1 & 6 & 22 & $\begin{array}{l}\text { Target 2020: political goal of the Federal } \\
\text { Government, target } 2030 \text { based on [65], } \\
\text { target } 2050 \text { taken from [9]. }\end{array}$ \\
\hline & $\begin{array}{l}\text { 18. Final energy productivity of the German } \\
\text { economy }(€ / G J)\end{array}$ & 366 & 482 & 743 & \multirow[t]{3}{*}{ Targets taken from [9]. } \\
\hline & $\begin{array}{l}\text { 19. Final energy productivity of the industry } \\
(\in / G J)\end{array}$ & 306 & 403 & 621 & \\
\hline & $\begin{array}{l}\text { 20. Final energy productivity of trade, } \\
\text { commerce and services }(€ / G J)\end{array}$ & 1602 & 2111 & 3251 & \\
\hline & $\begin{array}{l}\text { 21. Energy-related greenhouse gas emissions } \\
\text { (mio. } \mathrm{t} \text { of } \mathrm{CO}_{2} \text { eq.) }\end{array}$ & 622 & 467 & 207 & $\begin{array}{l}\text { Targets derived from political goals of the } \\
\text { Federal Government. }\end{array}$ \\
\hline & $\begin{array}{l}\text { 22. Energy-related emissions of acid-forming } \\
\text { gases (in mio. t of } \mathrm{SO}_{2} \text { eq.) }\end{array}$ & 0.93 & 0.85 & 0.69 & $\begin{array}{l}\text { Targets developed by analogy based on the } \\
\text { amendment of the Gothenburg Protocol } \\
\text { (see [67]) and own assumptions. }\end{array}$ \\
\hline & 23. Energy-related hazardous solid wastes ( $\mathrm{t}$ ) & \multirow[t]{2}{*}{789,223} & \multirow[t]{2}{*}{526,148} & 0 & \multirow{2}{*}{$\begin{array}{l}\text { Target } 2050 \text { based on assumptions, linear } \\
\text { extrapolation for } 2030 \text { and } 2020 \text {. }\end{array}$} \\
\hline & $\begin{array}{l}\text { 24. Amount of high-level radioactive waste } \\
\text { which has not been transferred to a safe } \\
\text { final disposal site ( } \mathrm{HM} \text { ) }\end{array}$ & & & 0 & \\
\hline & $\begin{array}{l}\text { 25. Installed capacity of renewable energy } \\
\text { power plants (GWp) }\end{array}$ & 116 & 144 & 169 & Targets taken from [9]. \\
\hline & $\begin{array}{l}\text { 26. Number of university graduates in the } \\
\text { field of energy sciences }\end{array}$ & 2702 & 2516 & 2919 & $\begin{array}{l}\text { Targets developed by analogy based on [9] } \\
\text { and assumptions. }\end{array}$ \\
\hline
\end{tabular}


Table 2 Sustainability Indicator System targets for 2020, 2030 and 2050 (Continued)

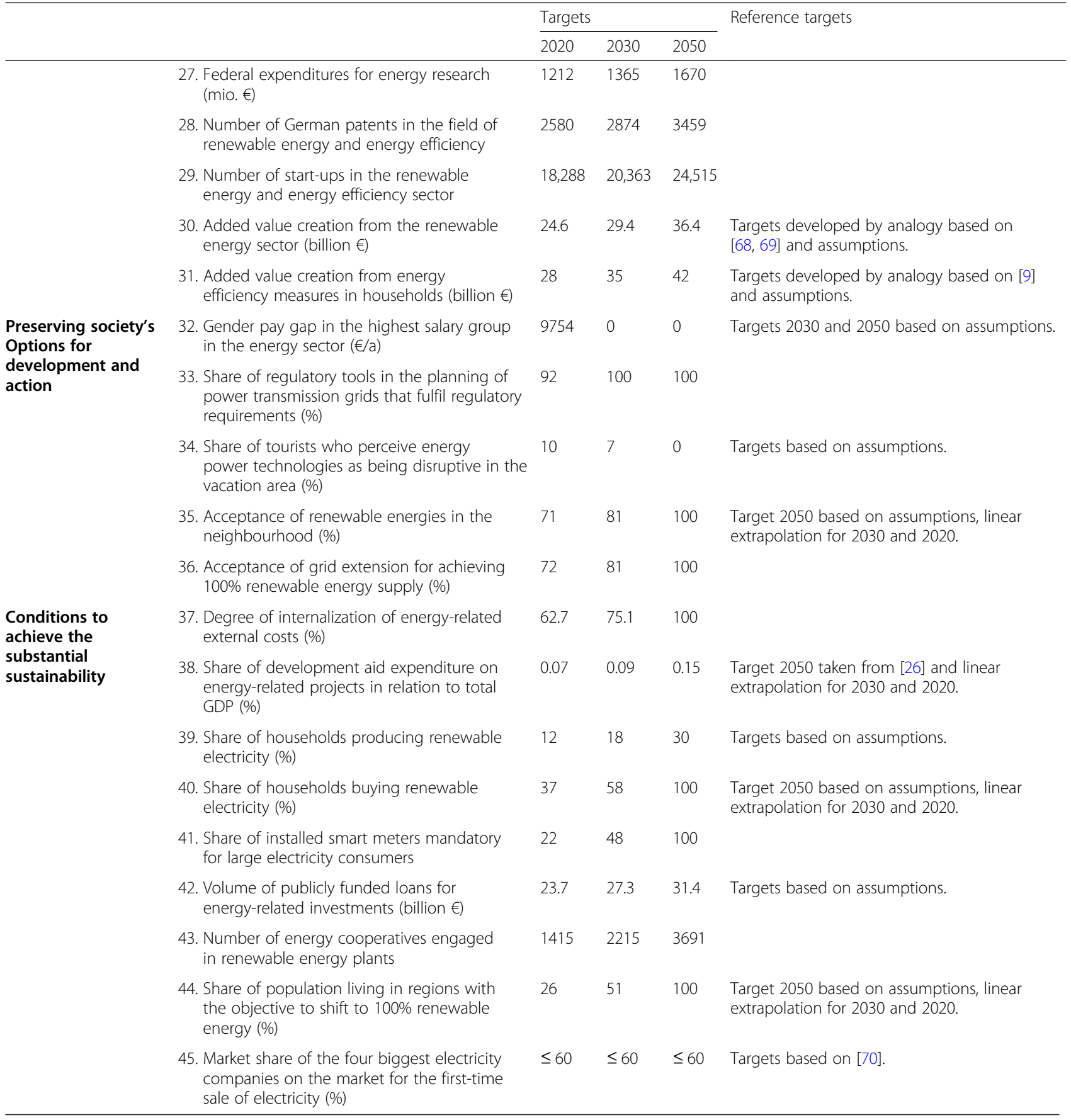

and full and productive employment and decent work are required to achieve sustainable development at different scale. This goal is integral part of the German sustainability strategy [10]. In the light of this and due to the threat of increasing underfunding of the social security systems, the German Federal Government wants to make better use of the existing workforce potential. The political target is to increase the employment rate, i.e. the proportion of the workforce in the population of working age (20 to 64 years old) to $78 \%$ and the employment rate of older (60- to 64-year-olds) to $60 \%$ by 2030 [11]. To achieve these targets, labour demand deriving from private companies and the public sector is of crucial importance.

The energy sector is an important employer, and the continuing growth of jobs in the renewable energy sector is significant. This increase is driven by declining renewable energy technology costs and enabling policy 


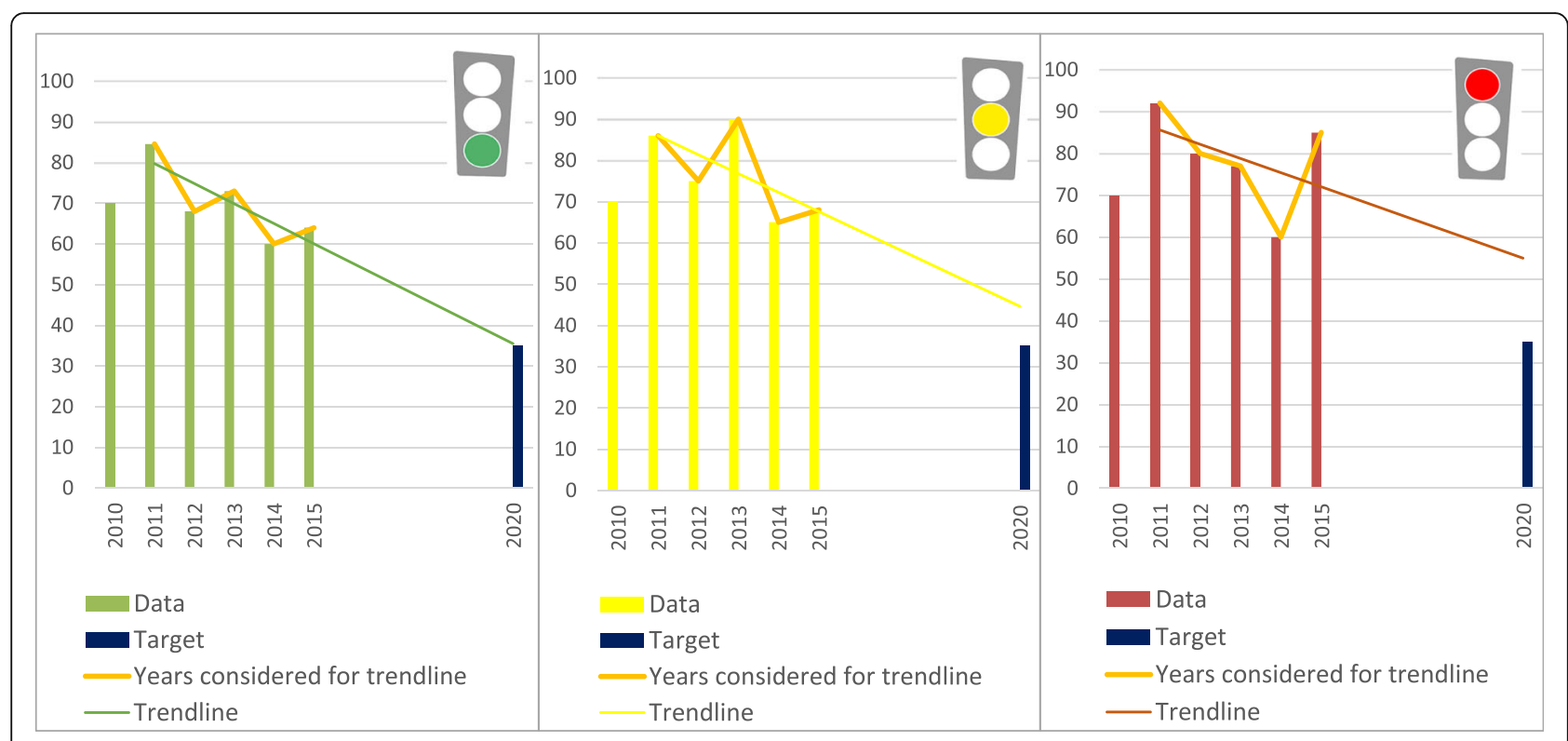

Fig. 1 Sustainability indicator assessment with the distance-to-target approach

frameworks. The labour demand and employment in the renewable energy sector mainly depend on economic growth, but also on changes in labour productivity (real gross domestic product per hour of employment) and working hours. Additional demand for labour can be compensated for by a higher yield of the individual working hour (productivity) or by additional work of the employees. Thus, if the renewable energy sector shows real growth that does not mean that the share of employees rises too. For the actual demand for labour, the macro-economic labour productivity plays a decisive role. For example, if growth is about 3\% and labour productivity is due to automatization and digitization also about 3\%, the growth-induced increase in demand for labour and the productivity-related decline in labour demand balance each other out. Only when the growth of production exceeds the increase in productivity the volume of work will increase and additional jobs are created. In order to define an indicator that can be communicated and understood easily, we agreed to use the comprehensive perspective assuming that the relationship between labour demand, productivity and overtime work and other influencing factors in the renewable energy sector remains unchanged.

The indicator 'share of employees in the renewable energy sector in relation to total number of employees' was selected, although we were fully aware that jobs in this new sector will reduce employment in the 'old' fossil fuel-based energy sector. Besides, employment in other sectors could decline due to increasing energy costs caused by a higher share of expensive renewable energy. Furthermore, employment could decrease in the future if the new energy sector turns out to be very efficient over time. An increase in the efficiency of electricity production is linked with a decrease in labour costs that could improve the overall employment rate. In view of these considerations, the defined indicator is regarded as provisional indicator that need to be improved or even replaced by a more comprehensive one including all direct and indirect employment effects of the energy transition if data are available.

The provisional indicator 'share of employees in the renewable energy sector in relation to total number of employees' includes the employment due to domestic production for domestic use and for exported renewable energy compounds, also employees responsible for maintenance and operation of renewable energy plants. However, the indicator excludes employment due to the production in other countries, e.g. the production of photovoltaic modules in China, since the sustainability analysis is focusing on Germany. A decline of employees in the conventional energy sector and other sectors as direct consequence of the energy transition is not taken into account, also higher energy costs resulting from subsidies for renewable energies (indirect effects) due to the lack of reliable data series.

This indicator shows continuously increasing values from 2007 to 2012 (Fig. 2), mainly because the number of employees in the renewable energy sector steadily increased from 277,300 in 2007 to 399,800 in 2012 . Then, the number decreased to 371,400 in 2013 , to 355,000 in 2014 and to 330,000 in 2015 [7, 12, 13]. The share of employees in 2007 to 2015 was calculated based on these data and data of total employees given in [14]. 


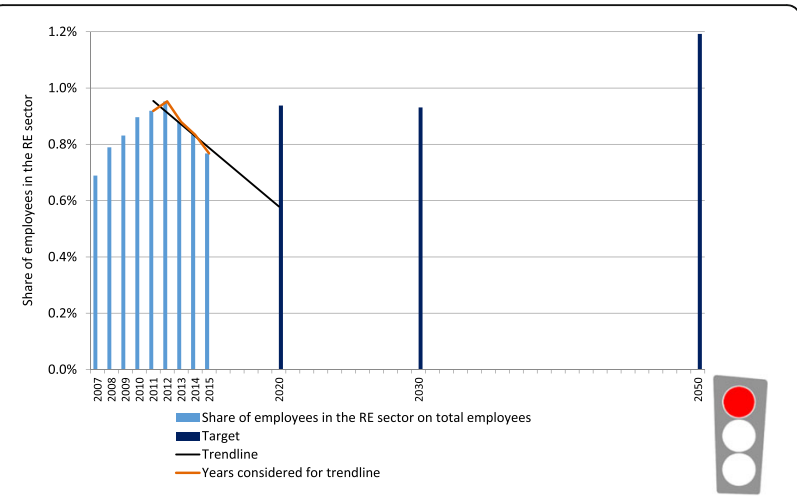

Fig. 2 Share of employees in the renewable energy sector in relation to total number of employees

The number of employees in the renewable energy sector mainly depends on the volume of investments into this sector in Germany, the export of renewable energy technologies, and the maintenance and operation intensity of renewable energy plants. Model-based information on the volume of investments in Germany until 2050 is given in [9]. Data on future exports and for employees responsible for maintenance and operation of renewable energy plants are not available. Therefore, the authors estimated the number of employees for the years 2020, 2030 and 2050 based on the estimated volume of investments in the field of renewable energy. In 2015, investments in the construction and maintenance of renewable energy plants (not investment in general) amounted to 15 billion euros [7] and the number of employees was 330,000 . The yearly volume of future investments has been taken from [9]. It accounts for 18.4 billion euros until 2020, 17.2 billion euros until 2030, 18.7 billion euros until 2040 and 19.9 billion euros until 2050 [9]. Based on these numbers, 416,000 employees for 2020, 387,000 employees for 2030 and 449,000 employees for 2050 were calculated. However, an even larger increase of gross employment from 530,000 to 640,000 people in 2030 would be possible assuming that a global technological leadership of the German industry also leads to a considerable competitive advantage on the growing future world energy market [9].

According to [14], the total number of employees was 41.5 million in 2011 and 43 million in 2015. Starting from the average value of $0.87 \%$ over the past 5 years (2011-2015), the following targets for the share of employees in the renewable energy sector to total employees can be calculated, using the data given in [9] for the renewable energy investments and the total number of employees:

- Target for 2020: 0.94\% (361,925 employees in relation to 38.6 million employees in total)
- Target for 2030: 0.93\% (336,989 employees in relation to 36.2 million employees in total)

- Target 2050: 1.19\% (391,004 employees in relation to 32.8 million employees in total).

The increase in employees according to the investments in the renewable energy sector required to achieve the energy targets of the Federal Government are comprising assumptions on increase in productivity. Decoupling of economic growth and employment in general and in the renewable energy sector respectively due to automation and digitization was not considered. Under these assumptions, the calculated trendline to 2020 shows a decrease of about $34 \%$, whereas the target recommends an increase of about $8 \%$. This leads to the assignment of a red traffic light for this indicator.

\section{Energy expenditure of low-income households}

Experiences in Germany show that the energy transition leads to growing energy expenditures of households because the costs to increase the share of renewable energies are allocated to customers through the EEG shared contributions. This allocation system has been discussed controversially. The impact of this financial burden on the energy expenditures of low-income households has been associated with terms such as 'energy poverty' or 'fuel poverty'. However, there is little agreement even on the problem definition and the measuring method. Moreover, evidence exists that the assessment if and to which extent 'fuel poverty' exists strongly depends on the measuring method used [15]. Hence, the authors refrained from an evaluation of data without mathematical methods carried out in [16] and propose to determine 'essential expenditures' of low-income household for an adequate energy supply for electricity and heating, according to the recommendation of [16]. The statistically raised data about energy expenditures of low-income households should be compared to these 'essential expenditures'. Not surprisingly, these values have not been determined (even not discussed) in Germany or other countries for different household types, since this is a highly normative decision, hardly justifiable in 'objective' terms. In fact, these expenditures are raised and used to date only within the English Household Survey and were used in the model BREDEM to investigate 'energy poverty' in the United Kingdom (UK). Besides the lack of appropriate poverty targets available from other countries, we chose the target from the UK, because the climatic and economic conditions in the UK are similar to those in Germany.

Beyond the fact that this approach is suitable in general, but not operable to date, the authors propose to refer on the indicator 'monthly energy expenditures of households with a monthly net income less than 1,300 
euros' as a first approach to monitor if the energy transition leads to undesirable additional financial burden. If this might be associated with the term 'energy poverty', remains open to discussion. The monthly net income of households is categorized according to the German Federal Statistical Office and calculated by subtracting income and wage taxes, church tax, and the solidarity surcharge as well as the mandatory social security contributions from gross household income consisting of the total income of the household from employment, property, public and private transfers and subletting. Data for the monthly energy expenses from 2002 to 2012 for the income class below $1300 €$ have been taken from [17]. They include electricity, fees, fuel costs for heating and taxes or levies on heating plants. To derive a data series of 5 years, data for 2013 have been calculated from information given in [18] and are the weighted average of the income classes below $500 €$ (2.6\% of this household group), 500 to $900 €$ (39.5\% of households) and 900 to $1300 €$ (57.9\% of households). Data for 2014 and 2015 are taken from [19, 20].

In principle, the target for this indicator would have to be adjusted over time considering the development of the income of the group concerned, the development of energy prices and the inflation rate. Since these values are not known, no prediction was made by the authors. Instead, the authors used research results on 'energy poverty' from the UK, where most research on this issue is carried out in the EU. According to [21], in the UK, the expenditure of low-income households on heating should not exceed $10 \%$ of their income. A higher percentage would indicate 'fuel poverty'. Despite the critical view of [22] on the data from [21], the authors decided to use this percentage to determine the target, simply because no other valid data were available to define a 'German standard'. On average, German households spend $70 \%$ of their energy expenditure on heating and $30 \%$ on electricity [23]. By weighting these two values, in Germany, the expenditures for heating and electricity should not exceed $15 \%$ of the net disposable household income of low-income households. Households in the category 'net income below $1300 €$ ' had on average a net income of $901 €$ in 2011 [17] and $916 €$ in 2015 [19]. Based on these data, values of expenditures for heating and electricity of $135 €$ in 2011 and $137 €$ in 2015 (Fig. 3) were derived.

The data for the period 2011 to 2015 show that households with a net income below $1300 €$ spend on average $89 €$ per month for energy use (Fig. 3). Based on the data for the past 5 years, values for the net income for 2020, 2030 and 2050 have been calculated. For the target values, $15 \%$ of these net income values have been assumed corresponding to $139 €$ in $2020,142 €$ in 2030 and $147 €$ in 2050. Since the trendline shows a decreasing monthly

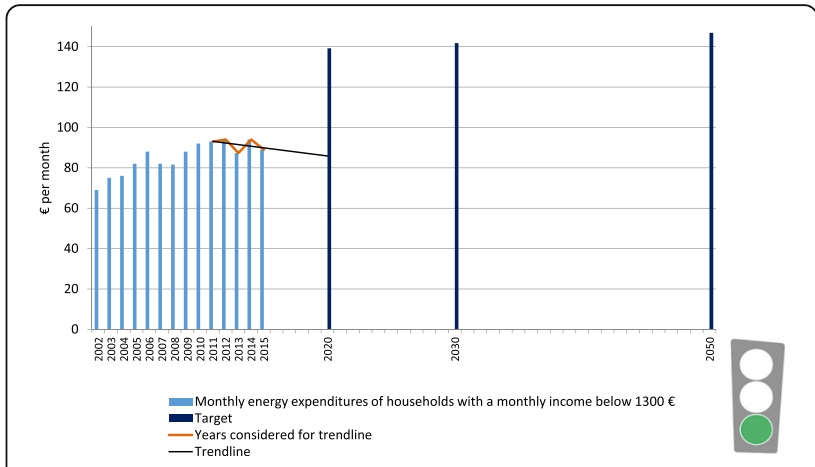

Fig. 3 Monthly energy expenditures of households with a net income below $1300 €$

expenditure not reaching the target value for 2020, a green traffic light was assigned to this indicator. Despite the green traffic light, however, there might be households who suffer from 'energy poverty' because their income is below the average of all households with incomes below 1300 Euro, which was used as database here.

\section{Area under cultivation of energy crops}

For the cultivation of energy crops, agricultural land is required. Land, however, is a finite and increasingly scarce resource. This leads to competition or even conflicts with other land uses, such as for food, feed and fibre production. Land is also needed for the installation of renewable energy plants, such as biogas plants, open space PV systems or wind energy plants, as well as power transmission lines. Compared to the land use requirements for conventional energy production with fossil fuels, for example for the installation of power plants or mining of brown coal, the energy transition towards renewable sources is associated with a higher land use. Land use data for the cultivation of energy crops are given in [24]. However, the different kinds of land use listed in [25] should not be summed up, because they are associated with different sustainabilityrelated impacts. In addition, parts of the land occupied by energy production can still be used for other purposes or can be re-cultivated after the energy production phase. Therefore, the authors have decided to take into consideration only land use for the cultivation of energy crops.

The cultivation of energy crops requires agricultural land and, therefore, will further lead to an increase of competition for land [1]. This growing demand can be satisfied by extending cropland and pastures into new areas, thereby replacing natural ecosystems, and/or by improving productivity of existing cultivated land through an increasing or more efficient use of inputs, improvement of agronomic practices and crop varieties, etc. Both options have negative environmental impacts, for example on the conservation of 
biodiversity. The import of biomass for food, feed, fuels and industrial applications is regarded as an unsustainable strategy to reduce land use conflicts, because this will only shift such conflicts to other countries. The land footprint abroad to satisfy the German (bio) energy demand has not been taken into account here, because the system boundaries defined for the SIS only comprise processes located in Germany, and due to lacking of valid data. The trend calculated based on data for the past 5 years (2011-2015) shows an increase for this indicator of about $11 \%$ by 2020 compared to the average value for 2011 to 2015 (Fig. 4).

According to [26], it is necessary to determine limits for the area dedicated to energy cropping in order to minimize land use conflicts. The authors derived these limits from two general principles based on the Sustainable Development model. First, to reach the SDG no. 2 (stop hunger and all forms of malnutrition by 2030), the production of food must be given priority over the production of renewable energy sources or the use for terrestrial $\mathrm{CO}_{2}$ storage. Thus, it is hardly justifiable to convert arable land from food production to energy cropping. Second, land use for energy crops should not jeopardize the nature conservation target determined by the German Advisory Council on Global Change (WGBU). The WGBU has proposed that $10-20 \%$ of the total land area should be reserved for nature conservation to protect, restore and promote a sustainable use of terrestrial ecosystems and to minimize biodiversity loss. Since worldwide only $8.8 \%$ of total land area are designated as protected areas (category I-VI areas), the conversion of natural ecosystems to land cultivated for energy crops has to be rejected as a matter of principle. As a global benchmark, the WBGU recommends to allocate not more than $3 \%$ of the terrestrial area to energy cropping to avoid conflicts with nature conservation. Considerations of particular regional conditions and possibilities are indispensable to translate this global target into the national scale. As recommended in [26], a maximum of $10 \%$ of arable land and 10\% of pasture land should be used for the cultivation of energy crops in Europe. According to

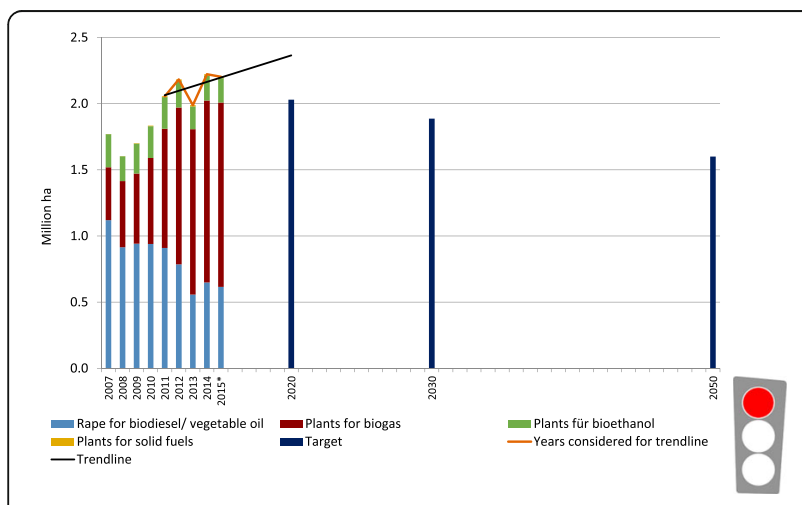

Fig. 4 Area under cultivation of energy crops
[26], these two percentages correspond to an area of 22 million ha or $4.5 \%$ of the land area available for the cultivation of energy crops in the European Union due to the decline in agricultural land.

This target is used for calculating the potential area in relation to the total land area of 34.9 million ha in Germany [27]. In doing so, the calculated target to be achieved by the year 2050 is about 1.57 million ha used for energy crops as a maximum. The targets for the years 2020 and 2030 were derived by interpolation from the target for 2050. Based on the average value of 2.13 million ha for energy crops over the years 2011 to 2015 and the target for 2050, the following targets were derived by linear interpolation: for the year 2020 a target of 2.0 million ha (5.6\% of the land area of Germany) and for the year 2030 a target of 1.9 million ha $(5.4 \%$ of the land area of Germany). In order to achieve the target of 2.0 million ha for 2020 , a reduction by $4.7 \%$ of the energy crops area compared to the mean value of 2.13 million ha for the years 2011 to 2015 is required. Since the trendline shows a further increase in the area under cultivation of energy crops, this indicator is aligned with a red traffic light.

The traffic light evaluation has to be discussed against the background of the defined target value in 2020 and the ongoing debate on bioenergy. Nevertheless bioenergy contributes to the Renewable-Energy Directive 2009/28/EC (which sets a target of $10 \%$ renewable energy in transport) and only biofuels meeting the binding sustainability requirements may count on the obligations, the cultivation of energy crops and even the energetic use of biomass is under increasingly controversial debate in Germany. The reason is that energy crops compete with other biomass uses, such as food and feed, and can be associated with negative effects on humans and the environment. This includes a change in global land use mainly driven by the expansion of bioenergy use in industrialized countries but also an increasing demand for animal products and correspondingly high feed requirements in emerging markets. In addition, the increased biomass demand is triggering an expansion of the agricultural production area, which could lead to the loss of valuable ecosystems such as forests and species-rich grassland. An intensification of agricultural production by an increasing use of synthetic fertilizers and pesticides can also be associated with ecological drawbacks, e.g. the loss of weed and landscape elements that are valuable for biodiversity. In view of these challenges and risks, it cannot be ruled out that the science-based target defined for the area under cultivation of energy crops in 2020 could be set more ambitious (less or even no area of energy crops) by society since the success of the energy transition is not tied to the expansion of bioenergy. 


\section{Number of start-ups in the renewable energy and energy efficiency sector}

While innovation is widely considered to be an important engine of the energy transition in Germany and a basic prerequisite to the general sustainability goal of 'maintaining societies' productive potential', measuring innovation is not easy, since knowledge about innovation processes and results is often limited. Different approaches are available, and various attempts have been made to measure innovation. For instance, asking experts in their respective fields to identify major innovations can be one method. However, this provides a rather subjective perspective and it is difficult to gain an overall and continuous picture of innovation. Therefore, the authors propose to use more than one indicator to properly assess the energy-related innovation process at different stages on a quantitative basis, encompassing both, the input into the innovation process and its outcome. The selected indicators are, first of all,'number of university graduates in the field of energy sciences' and 'federal expenditures for energy research'. Research and development (R\&D) expenditures are often used as a proxy for innovation or technological progress. However, expenditure is an input for R\&D rather than an outcome of R\&D, which should be innovation. Therefore, the authors additionally propose the indicator 'number of German patents in the field of renewable energy and energy efficiency, since patent data and statistics on new technologies are increasingly used to measure innovation, using e.g. European Patent Office (EPO) data, which provides long time data series. Although patent data are frequently used as an innovation indicator, their application is discussed controversially due to the constraints that are associated with this approach [28]. The key argument is that not all patents represent innovation, nor are all innovations patented. Besides, there are a small number of highly valuable patents and a large number of patents with little value. Scherer and Harhoff showed in their survey of German patents in total that about $10 \%$ of the most valuable patents account for more than $80 \%$ of the economic value of all patents [29].

Against this background, the authors decided to select also the indicator 'start-ups in the renewable energy and energy efficiency sector,' since entrepreneurial activity can be seen as an outcome of innovation processes and an initiation of opportunities opening up in the changing energy market. Niche actors, such as start-ups, play an important role in the energy transition process because they can support the implementation of shifts in the socio-technical landscape [30] and explore, develop or advance innovative products and processes that are required to shape transition [5]. Particularly when it comes to the commercialization of new energy technologies, start-ups may capture entrepreneurial opportunities or provide complementary niche innovations to the current regime players [31, 32].
Data on 5000 business start-ups used to describe and analyse the indicator are derived from [33]. Data was classified according to the 'environmental goods and services sector' framework. Thus, the start-ups could be assigned to eight distinguished sectors of the green economy: climate protection, renewable energies, energy efficiency, emission prevention, recycling economy, resource efficiency, renewable resources and biodiversity. Only the firms in the renewable energy and energy efficiency sector were considered for this indicator, in order to avoid duplicates, e.g. firms that are active in more than one sector (Fig. 5). The numbers of start-ups taken from [33] differ significantly from those presented in [4] (based on [34]). One reason is that the Centre for European Economic Research [34] uses a more conservative method to ascribe start-ups to the renewable energy sector that is based on a keyword search within the company name and description. The Borderstep Institute, however, uses individual Internet-based research to classify the firms within the sample. In general, this indicator has the problem that the data series ends in 2013.

To determine targets for this indicator, it is assumed that the number of start-ups develops in proportion to the number of registered patents in the renewable energy and energy efficiency sector (indicator no. 28, see Table 1). Patents are regarded as crucial for companies to generate benefits as a pioneering company. In terms of start-ups, however, there is little information on their patenting behaviour and any influence of patents on the company's success [35]. Some studies on the functionality of the patent system suggest that this system, although intended to support smaller companies and start-ups, is more likely to be driven by the strategic patenting behaviour of large companies and the rapid growth of all patent applications, [36, 37]. Furthermore, uncertainty in patent enforceability leads to discrimination against small businesses and start-ups. Despite these concerns about the functionality of the patent

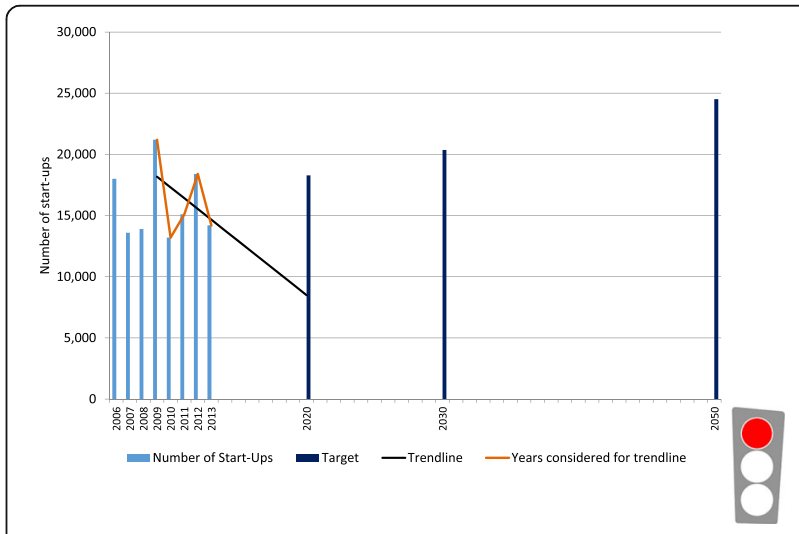

Fig. 5 Number of start-ups in the renewable energy and energy efficiency sector 
system for start-ups, arguments are repeatedly being made that start-ups can generate competitive advantages, above all through patents [38]. The main argument is that start-ups can capitalize on innovation only if innovation is protected and potential competitors are excluded from potential gains associated with innovation [35]. The number of newly registered patents, in turn, is assumed to depend on expenditures for energy R\& (indicator no. 27, see Table 1). A study by [39] shows that R\&D expenditure (in \% of GDP) in the OECD countries correlates significantly and positively with the so-called patent intensity. This indicates that countries with high R\&D expenditures also have high patent intensity. High expenditure on R\&D seems to be one of the most important prerequisites for a high level of invention activity. The German Government's Expert Commission on Research and Innovation [40] comes to the same conclusion: The commission states that $R \& D$ promotes the emergence of new knowledge and thus innovation and describes $R \& D$ as key drivers of international competitiveness and the long-term growth opportunities of economies.

Based on these findings, the target for the number of start-ups was assumed to develop in relation to the number of patents in the renewable energy and energy efficiency sector and the R\&D expenditures for energy in Germany respectively. The target for energy research expenditure in Germany was assumed to increase from $2.92 \%$ in 2013 to $4.36 \%$ of the GDP in 2050 . This corresponds to an increase by the factor 1.49 by the year 2050 compared to 2013. For the definition of this target, the sustainability goal of the sustainability strategy of the Federal Government, to spend 3\% of GDP on $R \& D$, was not adopted, because it was considered as not ambitious enough [10]. Instead, the target was defined by using the OECD country with the highest value in the category of research spending in relation to the GDP as reference point, which is South Korea with $4.36 \%$ in 2013 [41]. The research spending for the energy sector is assumed to increase also by the factor 1.49 to ensure that the share of energy research in total research spending remains the same. The same factor is applied to define the target for the number of start-ups in $2050(24,515)$. The average number of start-ups over the past 5 years for which data were available $(16,420)$ was used as initial value to derive the targets. The targets for the years 2020 and 2030 were interpolated accordingly, resulting in 18,288 start-ups in 2020 and 20,363 in 2030 (Fig. 5). The trendline calculated based on the past 5 years (2009-2013) shows a decrease in the number of start-ups of approx. $48 \%$ by 2020 compared to the average value over the years 2009 to 2013. Since the target for 2020 is $11 \%$ higher than the average value for the years 2009 to 2013, a red traffic light is assigned for this indicator.

\section{Gender pay gap in the highest salary group in the energy sector}

The pay gap between women and men is a relevant national sustainability indicator because it reflects equality in society [10]. Wage differences between women and men are a sign of social inequality in modern employment societies. Thus, the reduction in the gender pay gap is an indicator of progress towards equality and sustainable development. Still, women in Germany earn $23 \%$ less on average than their male colleagues [42]. In an EU-wide comparison, Germany is ranked on the seventh place from the bottom. With respect to university graduates and management positions, the gap is even wider. One main reason for this gap is that women are still very rarely represented in certain professions, sectors and on the upper end of the job career ladder. As the wage gap is a key indicator of the persistent gender inequality in working life used in political and scientific debates, we chose this for the SIS. The ratio between women's and men's gross yearly earnings addresses nearly all problems women are still confronted with in their working lives: women's limited access to certain jobs, obstacles they face in their professional development, traditional gender roles and mental patterns which hamper the reconciling of family and working life, including obstacles to re-enter labour market after a career break due to child care. Each of these factors contributes to the pay gap, ultimately. An EU-wide comparison reveals that in Germany the gender pay gap in the sector electricity, gas, heat and cold supply belongs to those economic sectors with the highest gap [43].

Official statistics distinguish between five performance groups representing a rough categorization of the employees' activities according to the qualification profile of workplaces. This categorization was narrowed down to the 'highest salary group' for a clearer visualization and focusing on most relevant groups, and to ensure reliable data series from the Federal Statistical Office. This 'performance group 1' includes employees in a leading position with supervisory and discretionary authority such as employed managers, provided their earnings include, at least partially, non-performance-related payments. Employees in larger management areas who perform dispatching or management tasks are included as well as employees with activities that require comprehensive business or technical expertise. In general, the specialist knowledge is acquired through university studies.

The indicator selected is defined with respect to gross yearly income of full-time employees in the energy supply sector including special payments, according to the German Federal Statistical Office category 'D-Energy supply', which includes electricity, gas, heat and cold supply sector [44]. In 2015, women's salary amounted to $84 \%$ of men's salary, with an annual salary difference of around 16,000 Euros (Fig. 6). Until 2030, the target is 


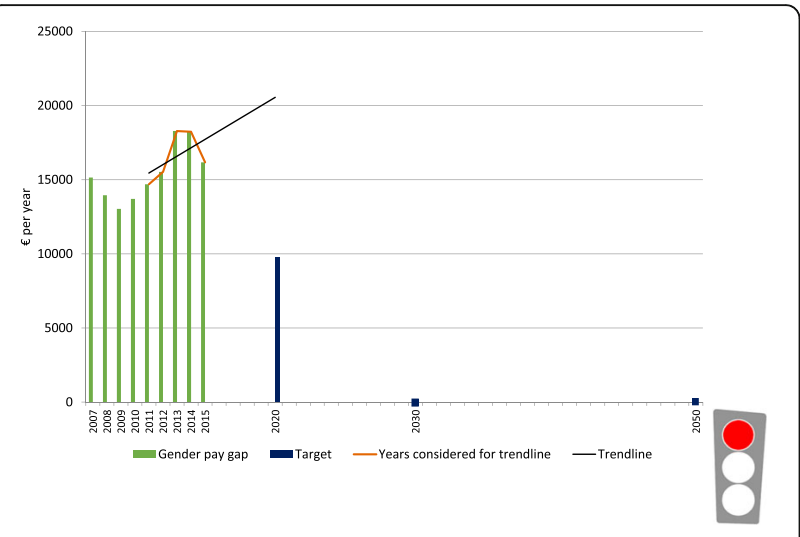

Fig. 6 Gender pay gap in the highest salary group in the energy sector

defined to eliminate this gender pay gap. The indicator and the target refer to the unadjusted gender pay gap by only relating the gross earnings to each other without considering their causes. This also includes the pay gap, which results from different factors such as career choice and employment biography of the respective cohorts. The defined target is more ambitious than the objective stated in the sustainability strategy (2016) of the Federal Government to reduce the gender pay gap to $10 \%$ by 2030 comprising gross hourly earnings at all salary levels and in all sectors [10]. The defined target for 2020 is determined by interpolating the average value of the last 5 years (2011-2015) and the complete closing of the gender pay gap by 2030. The extrapolated trend calculated for 2011-2015 shows an increase of the gap by $24 \%$ in 2020 compared to the average value over the years 2011 to 2015. This means that the indicator is assigned with a red traffic light and measures are required to reduce the gender pay gap in the highest salary group in the energy sector. Since the indicator is regarded to be representative for a variety of pay grades, also measures are needed to close the gender pay gap for other pay grades in the energy sector according to the sustainability principle equal pay for equal work or work of equal value.

\section{Acceptance of renewable energies in the neighbourhood}

While there are ambitious government targets to increase the share of renewable energy in Germany, it is increasingly recognized that social acceptance of renewable energy technologies may be a constraining factor in achieving this target especially due to changes in land use and landscape that are associated with these technologies. The farreaching changes in energy technology infrastructure and the landscape image associated with the energy turnaround are increasingly provoking intense resistance among the population. This is particularly apparent in the case of wind energy, which has become a subject of contested debates mainly due to visual impacts of plants on characteristic landscapes. Apparently, contradictions exist between public support for renewable energy innovation on the one hand, and obstruction or even resistance against the realization of specific projects in the neighbourhood, on the other hand. In this context, the question arises how it can be determined whether the energy transition towards renewable energies and the associated changes in resources, technologies and infrastructures are really accepted by citizens. Since general opinions on renewable energies usually reveal little information about social issues developing through the introduction of new renewable energy technologies and infrastructures and their retroactive effects on citizens, we have chosen the acceptance of renewable energies in the neighbourhood as indicator for the SIS. With this indicator, we can measure if citizens not only agree on the expansion of renewable energy in general, but would also accept to have a renewable energy plant in their backyard. This indicator addresses the socio-technical interface of the energy system since it can be measured if the technical energy transition is conform to political and social ideas and individual values.

Social acceptance is crucial for a successful energy transition, but difficult to assess with indicators because exploring the view of the subject on an object, and measuring different dimensions of acceptance and the influencing factors is a rather complex task and the field of renewable energies is highly diverse. In the present work, we have decided to use the results from different surveys in various years on the acceptance of renewable energies that was analysed on behalf of the German Renewable Energies Agency [45] since survey results are usually used to measure social acceptance and can give an impression of acceptance trends, if the same questions are asked over time. Measuring acceptance faces the problem to gather reliable and accessible data for the impact assessment and thus the assessment is quite often driven by the availability of data. For the selected indicator, data are available for Germany for the years 2010 to 2016 [46-49]. As desirable target for 2050, a total acceptance of renewable energy in the neighbourhood was assumed. Based on a linear interpolation between $100 \%$ in 2050 and the average value for the past 5 years (2011-2015), the targets for 2020 (72\%) and 2030 (82\%) were determined (Fig. 7). Compared to the average value for 2012 to 2016, the extrapolated trend calculated for the past 5 years (2012-2016) shows a decrease in the acceptance of renewable energy in the neighbourhood by $7.3 \%$ in 2020 . However, the target for 2020 requires an increase of $8.7 \%$ compared to the average value of 2012 to 2016 . Consequently, the indicator is rated with a red traffic light.

Since the reactive acceptance of renewable energy is strongly influenced by the technology used to produce 


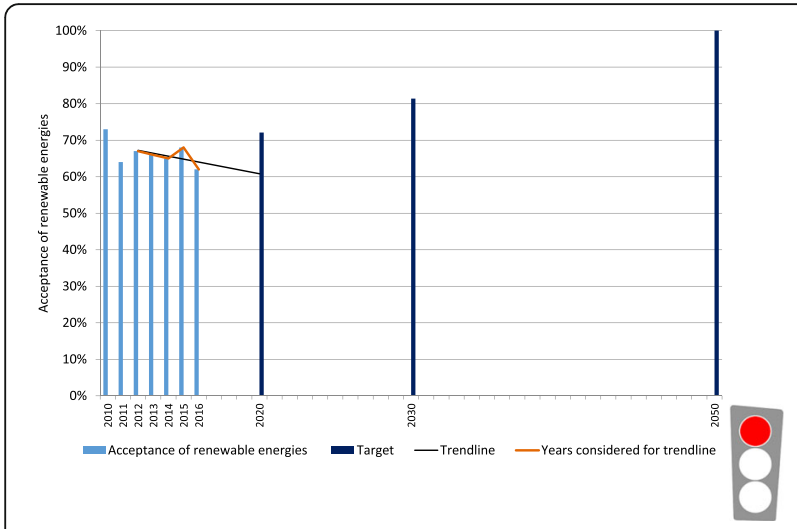

Fig. 7 Acceptance of renewable energy in the neighbourhood

renewable energy, it is important to also specifically measure the acceptance of the different renewable energy technologies. The data in Table 2 show the values for the acceptance of specific renewable energy technologies, such as wind turbines, biomass plants, photovoltaic systems (solar parks) and nuclear and coal-fired power plants. The percentages listed here are based on regular surveys and represent the sum of positive answer options 'I like that' and 'I like that very much'. Looking at renewable energy technologies in more detail, biomass and wind energy plants experience the lowest level of social acceptance, whereas solar energy to produce electricity with photovoltaic panels in solar parks receive the highest level of acceptance (Table 3).

In principle, acceptance issues cannot be fully covered by only one or two indicators. The acceptance of key energy transition technologies does not cover all issues that are relevant to assess to which extent energy transition paths are acceptable and will be accepted. Therefore, another indicator addressing grid extension is part of the indicator set. It should be emphasized at this point that despite the uncertainties how to operationalize and measure the acceptance of the energy transition in a relevant, robust and scientifically sound way, we believe that acceptance is a highly important research field to address the socio-technical interface of the energy system. Further research is needed to develop a reliable and meaningful set of acceptance indicators which can be sufficiently addressed with data over a time series in order to improve the transformation process constructively and with a view to all actors and citizens.

Degree of internalization of energy-related external costs Activities related to the energy system often cause environmental impacts and according costs. External costs occur if producing or consuming energy services imposes costs upon third parties, such as air pollution-related ecosystem or health impairment to individuals and according clean-up costs to the society. Therefore, internalization of external costs aims at making such effects part of the decision-making process of energy providers and users, reducing occurring market failures and minimizing negative impacts of the energy system on society's welfare. In order to estimate these costs, external effects of the energy system have to be identified, assessed and monetized, as far as possible. Internalization of external costs can be implemented by various policy measures, including marketbased instruments (e.g. charges, taxes or tradable permits). Accordingly, fair and 'true' energy pricing is assumed to make it economically more attractive to both, using energy services with fewer negative environmental effects and healthcare costs, and reducing energy use in total, in order to bridge the gap between private and societal costs of energy production and use. This is why the authors have chosen this indicator for the SIS.

The degree of internalization of energy-related external costs is defined here as the coefficient between taxes on energy use (energy taxes, electricity taxes, motor vehicle taxes, air transport taxes, nuclear fuel taxes and road taxes) and environmental and healthcare costs due to electricity production and energy use for heating and transportation. Data are given for the years 2008 to 2010 and are calculated based on methodological guidance given in [50]. Therefore, taxes on air transport and on nuclear fuels, established since 2011, are so far not included in the methodology and the numbers presented. Data on energy taxes, electricity taxes and motor vehicle taxes are taken from [51, 52], data on road taxes for trucks from [53] and data on environmental costs from [50].

According to [54], environmental costs resulting from the production of electricity in Germany include

Table 3 Acceptance of renewable energy technologies in the neighbourhood (data from [46-49])

\begin{tabular}{|c|c|c|c|c|c|c|c|}
\hline & \multicolumn{7}{|c|}{ Acceptance in the neighbourhood } \\
\hline & $2010(\%)$ & $2011(\%)$ & $2012(\%)$ & $2013(\%)$ & $2014(\%)$ & $2015(\%)$ & $2016(\%)$ \\
\hline Solar park & 74 & 77 & 77 & 72 & 72 & 77 & 73 \\
\hline Biomass & 40 & 36 & 36 & 39 & 39 & 39 & 38 \\
\hline Nuclear power plant & 5 & 2 & 3 & 3 & 5 & 4 & 5 \\
\hline Coal-fired power plant & 6 & 8 & 8 & 8 & 11 & 7 & 6 \\
\hline Wind turbines & 56 & 60 & 61 & 59 & 61 & 59 & 52 \\
\hline
\end{tabular}


environmental and healthcare costs that result from direct emissions. Costs resulting from indirect emissions over the entire life cycle of energy production have also been taken into consideration. Since indirect emissions arise not only in Germany, EU cost rates have been considered as well. The costs of greenhouse gas emissions are determined as $80 €$ per $\mathrm{tCO}_{2}$, including damage as well as abatement costs. Estimates of environmental and healthcare costs of nuclear energy differ widely within the literature available. Following the requirements of the methodological convention used here [54], the most expensive technology should be used for the calculations. In the case considered here, this is electricity production from lignite. Environmental costs of transportation include health effects, climate change effects, noise and impact on nature and landscape, as well as effects caused by indirect emissions (construction, maintenance and disposal, fuel supply).

Total environmental costs, defined as described, amounted to 122.4 billion $€$ in 2008, 115.2 billion $€$ in 2009 and 120.6 billion $€$ in 2010 [50]. In principle, data for other years can also be calculated by taking into consideration the mix of electricity production and heat energy consumption, as well as the relevant data for the transport sector for the different years. However, this is only reasonable if both the related environmental costs and the technologies (e.g. emission factors) do not change-an assumption that is not realistic. Thus, only calculations for other years are valid that take into account such changes. Based on the methodology described, in 2010, the degree of internalization of external costs amounted to $48.9 \%$ [50-53] (Fig. 8). An update beyond 2010 was not calculated because the results strongly depend on the development of emissions and the related healthcare costs. As target for 2050, a complete internalization of energy-related external costs was assumed. Based on a linear interpolation between 100\% in 2050 and the average value for the 3 years

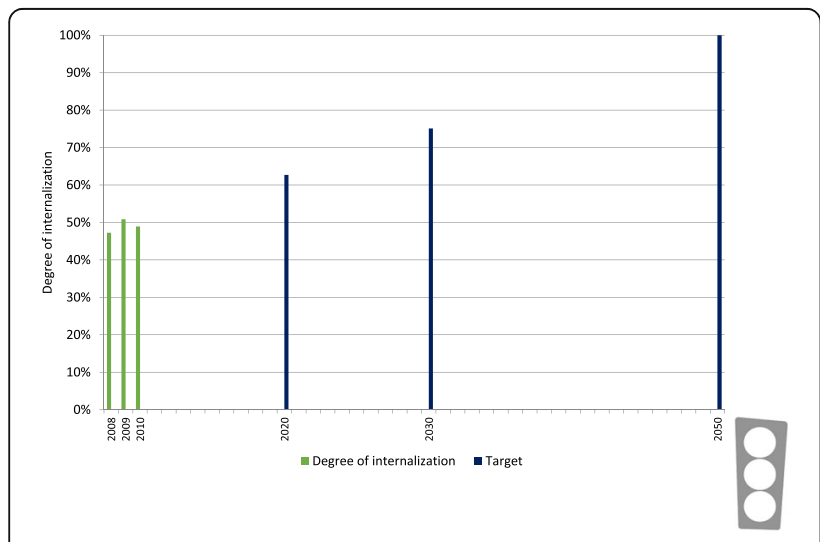

Fig. 8 Internalization of energy-related external costs with data available (2009-2010), the targets for 2020 and 2030 were determined as shown in Fig. 8. A white traffic light was assigned to this indicator because no trendline and distance-to-target were calculated due to the lack of a sufficient data series.

External costs of the energy system and its transition can be calculated by determining the social costs, which have been borne by the public, and integrate them into microeconomic cost accounting. The aim of this method is to attribute the external costs associated with environmental pollution with the help of prices to the polluter (polluter-pays principle). By this, a market-based and therefore system-compatible and effective solution to the environmental problem is provided. It has to be noted, however, that in environmental policy, it is regarded as not possible to fully internalize externalities because of the problems of economic assessment of environmental damage and the polluters. That is why the defined desirable target to completely internalize the energy-related external costs is quite ambitious.

\section{Number of energy cooperatives engaged in renewable energy plants}

In recent decades, thousands of people have joined citizen groups, city and local councils or local business enterprises to set up renewable energy projects. Energy cooperatives enjoy great popularity as a form of organization since in Germany a long tradition of cooperatives exists. The organizational form of the cooperative is based on the sustainability principles of solidarity, democracy, identity and membership promotion and has a high potential for democracy [55]. With their economic-democratic approach of involving the members in their entrepreneurial orientation, of forming a solidarity economy and moving away from the maxim of profit maximization, cooperatives are, at least ideally, counterparts to capitalistically organized companies and blueprints for sustainable organizational forms [56]. Moreover, energy cooperatives can play a central role in a participative oriented energy transition in terms of their design as prosumer organizations. They represent a model that tries to respond to the social and environmental challenges of modern societies with alternative business, economic and social models [55]. In energy cooperatives, citizens work together for the production and distribution of renewable and clean energy [57]. Not only the ecological claim, but also the democratically oriented logic of action, suggests that energy cooperatives are included in the discourse on sustainability, emphasizing their central role in the context of the energy transition and their transformative potential for social development processes as well as their potential for self-organization of society pursuing the decentral transition to clean energy, and thus become main actors of the energy transition [55]. Besides, energy cooperatives for local energy projects can contribute to 
a higher public acceptance of new systems to provide renewable energy. In the light of these considerations, we have decided to select the indicator 'number of energy cooperatives engaged in renewable energy plants' for the SIS. Various forms of energy cooperatives have been founded in Germany for more than a decade, allowing citizens to directly support the energy transition through own investments in and ownership of large-scale renewable energy plants that would be too expensive for single individuals alone, such as solar parks or wind turbines. To date, most energy cooperatives are formed at a local level, for example, by villagers investing in a nearby wind farm. Information about energy cooperatives is taken from [58-60] and includes local and regional citizens' cooperatives. Here, only energy cooperatives under the umbrella of the Deutscher Genossenschafts- und Raiffeisenverband e.V. are taken into consideration. According to these studies, the accumulated number of energy cooperatives was 8 in 2006, 272 in 2010 and 812 in 2015 (Fig. 9). According to these figures, the number of energy cooperatives in Germany has risen steadily in recent years. At the same time, however, it can be observed that annual growth rates are falling sharply. This can be explained above all by the changing conditions under the EEG. Thus, 129 new energy cooperatives were founded in 2013, compared to only 56 in 2014 and 40 in 2015. These figures may vary since some sources are based on the year of establishment, others on the year of registration. The contracts of these energy cooperatives include electricity production $(87 \%$ of all cooperatives in 2012 and $95 \%$ in 2013), heat production (19\% in 2012, $16 \%$ in 2013), grid operation (4\% in 2012 and 2013) and operation of district heating systems (20\% in 2012, $16 \%$ in 2013). Since the results are based on a survey where multiple answers were possible, the added single percentages exceed the total of $100 \%[59,60]$. Civil power plants produced approximately 580 million $\mathrm{kWh}$ of renewable

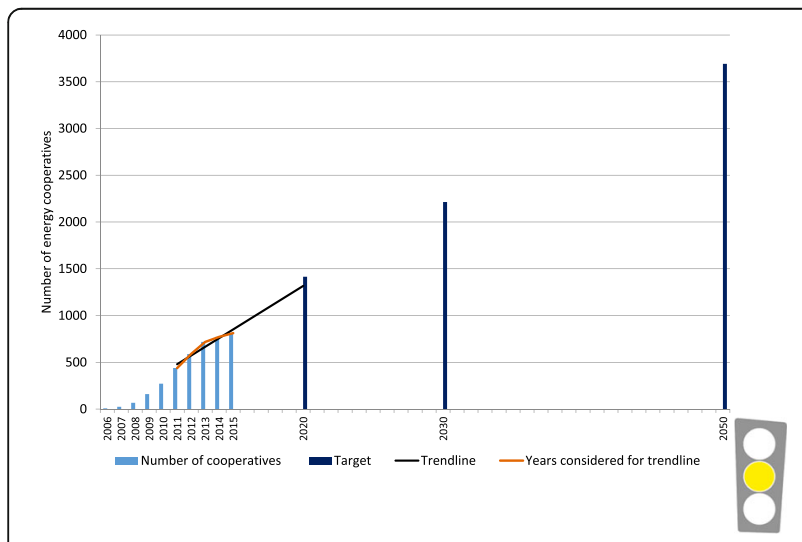

Fig. 9 Number of energy cooperatives electricity in 2012 and. 830 million kWh in 2013 [6, 47]. No data series are available for the number of people belonging to these cooperatives. Only for 2011, it is confirmed that more than 80,000 citizens were engaged in energy cooperatives.

To preserve the ability for self-organization in the field of renewable energies, we derived the targets for 2020, 2030 and 2050 by assuming that the number of energy cooperatives should rise proportionately to the increase of the 'share of renewable energy in gross final consumption of energy' (indicator no. 10, see Table 1).

The extrapolated trend calculated based on the past 5 years (2011-2015) leads to an almost doubling until 2020 compared to the average value for 2011 to 2015 . The target for 2020 (1415 cooperatives) requires an increase of $112 \%$ compared to the average values for the years 2011 to 2015 (666 cooperatives). This results in a deviation of $13 \%$, which was assigned with a yellow traffic light.

Above all, the framework conditions of support via the German Renewable Energy Act (EEG) are crucial for the number of energy cooperatives. The EEG amendment, which came into force in 2017, switched from fixed feed-in tariffs to competitive tenders. By this, projects of energy cooperatives are disadvantaged systematically. With the aim of preserving the important diversity of actors involved in the energy transition in general and the organization model of energy cooperatives respectively, facilitated participation conditions have to be defined for citizens' energy projects. Since the share of renewable energy in gross final consumption of energy is still rising significantly and continuously while at the same time fewer and fewer energy cooperatives are founded, a drastic change in the framework conditions of the EEG is required to achieve the targets for 2020 and beyond.

\section{Sustainability assessment of the German energy system}

Figure 10 gives an overview on the evaluation results for all 45 indicators selected for the sustainability assessment of the German energy system. Only for 12 indicators it can be assumed that the sustainability targets for 2020 can be achieved without additional or changes of policy measures (green traffic light). Four indicators are aligned with a yellow traffic light. Political action is needed to reach the targets for 18 indicators assigned with a red traffic light. Another 11 indicators are assigned with a white traffic light due to the lack of available data series. It can be noted that indicators related to the maintenance of society's productive potential with regard to use of rentable and non-renewable resources as well as environment pollution (nos. 10 to 22) are all rated with a red traffic light, except the indicators 'final energy productivity of the industry' (no. 19) and 'energy-related emissions of acid-forming gases' (no. 22). The indicators assessing the sustainable development of human capital (nos. 26 to 29), however, are mainly evaluated with a 


\begin{tabular}{|c|c|}
\hline \multirow{9}{*}{ 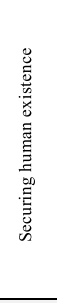 } & 1. Energy-related emissions of particulate matter \\
\hline & 2. Energy-related emissions of cadmium \\
\hline & 3. Energy-related emissions of mercury \\
\hline & 4. Energy import dependency \\
\hline & 5. Monthly energy expenditures of households with a monthly net income less than 1,300 Euros \\
\hline & 6. SAIDI of electricity \\
\hline & 7. Relation of employees in the renewable energy sector to total employees \\
\hline & 8. Final energy consumption of private households per capita \\
\hline & 9. Relation of technician salary to manager salary at the big electricity suppliers \\
\hline \multirow{22}{*}{ 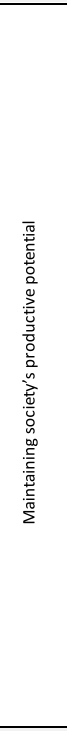 } & 10. Share of renewable energy in gross final consumption of energy \\
\hline & 11. Area under cultivation of energy crops \\
\hline & 12. Unused renewable electricity due to management measures \\
\hline & 13. Use of primary energy \\
\hline & 14. Specific final energy consumption of households for heating (temperature-corrected) \\
\hline & 15. Final energy consumption in the transport sector \\
\hline & 16. Modal split in the transport sector \\
\hline & 17. Number of electric vehicles \\
\hline & 18. Final energy productivity of the German economy \\
\hline & 19. Final energy productivity of the industry \\
\hline & 20. Final energy productivity of trade, commerce and services \\
\hline & 21. Energy-related greenhouse gas emissions \\
\hline & 22. Energy-related emissions of acid-forming gases \\
\hline & 23. Energy-related hazardous solid wastes \\
\hline & 24. Amount of high-level radioactive waste which has not been transferred to a safe final disposal site \\
\hline & 25. Installed capacity of renewable energy power plants \\
\hline & 26. Number of university graduates in the field of energy sciences \\
\hline & 27. Federal expenditures for energy research \\
\hline & 28. Number of German patents in the field of renewable energy and energy efficiency \\
\hline & 29. Number of start-ups in the renewable energy and energy efficiency sector \\
\hline & 30. Added value creation from the renewable energy sector \\
\hline & 31. Added value creation from energy efficiency measures in households \\
\hline \multirow{5}{*}{ 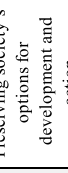 } & 32. Gender pay gap in the highest salary group in the energy sector \\
\hline & 33. Share of regulatory tools in the planning of power transmission grids that fulfil regulatory requirements \\
\hline & 34. Share of tourists who perceive energy power technologies as being disruptive in the vacation area \\
\hline & 35. Acceptance of renewable energies in the neighbourhood \\
\hline & 36. Acceptance of grid extension for achieving $100 \%$ renewable energy supply \\
\hline \multirow{9}{*}{ 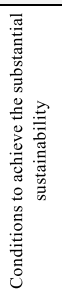 } & 37. Degree of internalization of energy-related external costs \\
\hline & 38. Share of development aid expenditure on energy-related projects in relation to total GDP \\
\hline & 39. Share of households producing renewable electricity \\
\hline & 40. Share of households buying renewable electricity \\
\hline & 41. Share of installed smart meters mandatory for large electricity consumers \\
\hline & 42. Volume of publicly funded loans for energy-related investments \\
\hline & 43. Number of energy cooperatives engaged in renewable energy plants \\
\hline & 44. Share of population living in regions with the objective to shift to $100 \%$ renewable energy \\
\hline & 45. Share of the four biggest electricity companies on the market for the first-time sale of electr \\
\hline
\end{tabular}

Fig. 10 Sustainability assessment of the German energy system

green traffic light. Here, action is only required to improve the performance of the indicator 'numbers of start-ups' (no. 29).

As described in [8], it was not possible to define suitable indicators for all sustainability aspects affected by the energy transition. This was the case, for example, for the issue of preserving biodiversity. However, biodiversity could be measured by using several indicators of the Sustainability Indicator Set (SIS), as some of them measure driving forces considered as mainly responsible for the loss of biodiversity [61]. Some driving forces, such as the extent of land use, are listed in the SIS or can be translated into adequate indicators. This was done for the load of nutrients and pollutants that is referring to the indicators eutrophication and acidification and discharge of heavy metals (Fig. 11). Only one main driving force-the occurrence of invasive species-is not reflected in the SIS at all.

As shown in the overview of results in Fig. 11, seven indicators are regarded as relevant for the preservation of biodiversity. Of these, four are rated with a red traffic light and two with a white traffic light. These results indicate that the transition of the energy system will rather contribute to the loss of biodiversity than to stop it. However, the targets for these indicators were not derived to address biodiversity aspects explicitly. Therefore, the statement is accordingly provisional and uncertain. Regarding the pollution of ecosystems due to the discharge of heavy metals, however, the critical load concept should be used for the assessment 


\begin{tabular}{|c|}
\hline Land use, land use intensification and fragmentation (SI No. 11) \\
\hline Eutrophication and acidification (SI No. 22) \\
\hline Global warming caused by greenhouse gas emissions (SI No. 21) \\
\hline $\begin{array}{l}\text { Pollution due to the discharge of heavy metals (SI No. } 2 \text { and SI No. } 3 \text {, however the targets are related to human health not } \\
\text { to the critical loads for biodiversity) }\end{array}$ \\
\hline
\end{tabular}

Fig. 11 Indirect sustainability assessment of the impact of the energy system and its transition on biodiversity

rather than the emission values affecting the human health. For Germany, critical loads are available for lead $(\mathrm{Pb})$, cadmium $(\mathrm{Cd})$ and mercury $(\mathrm{Hg})$, taking into account both potential health effects and ecotoxic effects by measuring the maximum load of ecosystems. As a result of European mapping, critical load exceedances in Germany are widespread for $\mathrm{Pb}$ and $\mathrm{Hg}$, but hardly for $\mathrm{Cd}$ [62]. A review of these statements based on results of German deposition measurement networks in combination with dispersion models is not yet possible. For this reason, there are no spatially differentiated representations of critical loads for heavy metals by atmospheric immissions. Against this background, we recommend further research and empirical studies aiming at overcoming these limitations of measuring impacts of the energy system on biodiversity.

\section{Discussion}

The quality and reliability of assessments based on the Sustainability Indicator System (SIS) such as the one we presented in this paper depends on the appropriateness of the selected indicators, the availability of valid data series, targets determined and the evaluation method applied, e.g. based on the distance-to-target approach. These factors, their relationships and impacts on the assessment results will be discussed in the following. The discussion is focusing on the comparison of our results with those of the German monitoring report 'Energy of the Future' as this is the only official and the most elaborated and regularly revised approach to monitor the German Energiewende. Besides, it applies a similar procedure for the selection of indicators for economic and ecological impacts and the assessment of the indicator performances. Other studies such as the indicator report from the German Federal Office of Statistics or the Energiewende-Navigator developed by the Federal Association of German Industry (BDI) are not considered here (see [8]), because they are not as comprehensive and regularly updated as the German monitoring report. Besides, the BDI applies a different procedure for the assessment resulting in another traffic light system that is not comparable with the approach described here.

The discussion is focusing on those indicators that are used both in the SIS and the German monitoring report, but show divergent assessment results. Such differences occur in the case of four indicators addressing key targets of the energy transition: share of renewable energies in gross final energy consumption (SI no.10), primary energy use (SI no. 13), final energy productivity of the German economy (SI no. 18) and greenhouse gas emissions (SI no. 21). In our assessment, these indicators are all assigned with a red traffic light. Although the monitoring report also used the distance-to-target approach and the same data series (except for the greenhouse gas emissions where we included only the energyrelated emissions), the two assessment results are different. To understand the differences, it must be explained that the monitoring report applies an assessment scoring system ranging between 5 points for the fulfilment of a target up to a deviation of $10 \%$ to 1 point for a deviation over $60 \%$. Using this scoring method leads to the results that three of these four indicators (SI nos. 13, 18 and 21) were awarded with 3 points, whereas the indicator SI no. 10 was awarded with 5 points. In fact, the monitoring report assessment results of these four indicators are much more positive compared to the results presented here.

A further difference between our approach and the monitoring report, also responsible for the varying results, is the methodology chosen to assess the deviation between projected values and the targets for the year 2020 . As described before (see formula I in the 'Sustainability assessment based on the distance-to-target approach' section), we compare the projected change in percentage with the change required in percentage for calculating the deviation in percentage that is evaluated using the traffic light colour code. In contrast, the monitoring report compares the absolute values of the projected value with the target. We chose the percentage deviation because it provides information on both, the deviation of the present and the projected value from the present and future target. Besides, absolute values could result in misleading conclusions. This applies particularly to cases where the distance between the current value and the target is large, because comparing absolute values would lead to an overestimation of the degree of target achievement. On the other hand, using percentage values as basis for the assessment can lead to an underestimation of the target achievement degree in cases where the distance between the current value and target is small.

Another methodological difference exists with respect to the reference value used for the calculation of the 
projected value for 2020. In the monitoring report, the projected value was derived by a linear projection starting from the year 2008, which is fixed for all indicators. In our assessment, however, we use the average value of the period of the past 5 years with available data. Although for many indicators, data series up to the year 2015 or 2016 were available, this approach has the drawback that the indicators can have different reference periods. Despite this drawback, we have chosen this approach in order to better capture and integrate recent changes in trend development, e.g. due to modifications of societal framework conditions, such as regulation approaches. To give an example: With just 40 new energy cooperatives being set up in 2015, the number of newly founded cooperatives fell by another $25 \%$ compared to the previous year with an already low level. Such recent shifts are possibly overlaid in the monitoring report, as has been already stated in [63]. Löschel et al. criticize the monitoring report being not able to suitably consider the more or less stagnation of greenhouse gas emissions since 2009 with its methodological approach. In contrast, we assigned a red traffic light to this indicator, as a result of regarding the probability to reach the target set.

It has to be noted that the delimitation of the 5 -year period and the calculation of the reference value depends on the availability of data series. Consequently, the number of remaining years for political measures to achieve the 2020 target can differ. Considering a period closer to the target, e.g. from 2012 to 2016, would require stronger measures to achieve the target compared to an earlier time period, e.g. 2008 to 2012, because fewer years remain for interventions and measurable impacts. Thus, it may be reasonable to adjust the reference lines to assign the traffic light code over time. Moving closer to the target year 2020, the need for action is more urgent, and thus, the traffic light should turn, e.g., from a red light into a dark red light, accordingly a green traffic light could turn into a yellow one. Compared to the approach chosen, such a modification could better fulfil fairness considerations in the distance-to-target approach, but it would definitely make the assessment more complicated and require difficult decisions how to adjust the traffic light colour code in detail. On the other hand, a green traffic light based on the past and extrapolated trend may lead to the conclusion that the distance to the target is so close that the target will be reached easily and thus efforts could be slowed down and even reverse earlier progress. Then, action to achieve the targets at least in 2030 or 2050 would be again necessary. This phenomenon can be tackled by focusing on rates of improvement rather than on distances to target. Dynamic assessments can also suggest the degree of effort required to meet a target, and how this varies across targets: where there is a long distance to travel, but recent progress has been rapid, it may be easier to close the gap than where the initial distance is short but recent progress has been slow or negative.

A further reason for the differences in the results between our assessment and the monitoring report are the targets determined for the indicators. Löschel et al. assessed the indicator SI no. 13 ('use of primary energy') with a yellow traffic light and the indicator SI no. 10 ('share of renewable energy in gross final consumption of energy') with a green traffic light, meaning that it is likely that the targets for 2020 can be achieved with current policies and strategies. For SI no. 10, we choose a more ambitious target for 2020 . Instead of $18 \%$ share of renewable energy, a share of $23 \%$, based on [9], was determined to ensure a better consistency with other assumptions also taken from [9]. Hence, we assigned the SI no. 10 with a red traffic light, in contrast to the green traffic light in the monitoring report. This example shows the influence of target setting on the assessment results.

Our approach to define targets for each indicator of the SIS regardless of whether these are already politically or legally anchored targets in order to carry out comprehensively the DDT assessment has strengths and limitations. The strength of the approach is that it provides a preliminary comprehensive overview of the sustainability of the energy system in Germany and its transition. The restriction of the approach is that the assessment results have to be considered differentially since those targets, which are not reflecting political binding targets, are provisionally as long as they are not justified by politics. Furthermore, it has to be noted that even for those indicators where binding political targets exist, these targets can be revised accordingly if it is likely that the objectives will not be met. A current example of this is the agreement between the biggest parties in Germany to give up officially the already unattainable climate targets for 2020 .

Another restriction is that the translation of targets irrespective of their origin into quantitative numbers for 2020, 2030 and 2050 appeared to be not a straightforward, but a complex and rather difficult task, due to several reasons. One challenge is that not all targets can be easily expressed in quantitative terms or can be translated into quantitative reductions and modifications of existing numbers. In those cases when the policy target refers to a year different from 2020, e.g. a period in time beyond 2020, the target for this year had to be re-scaled through linear interpolation. This necessary procedure is regarded as a second source of uncertainty. Despite these restrictions and uncertainties, the DTT assessments can clearly help to identify the need for political priority setting and action respectively in those areas that are highly relevant for the sustainable development of the energy system and its transition but have been excluded or overlooked so far. 
As outlined above, we have applied existing policy targets if possible to be compatible for political decisionmakers and provide applicable information. In view of the influence of the target definition on the assessment result, it can be criticized that targets should be defined according to scientific evidence rather than political feasibility. The debate on climate protection shows that this would probably lead to more ambitious targets and to a worse rating of the transformation strategies implemented. In our assessment, however, for many indicators, this would not have changed the alignment of the already red traffic lights and the recommendation that action is required to reach the quite ambitious political targets. For the new indicators that are not yet on the political agenda of the energy transition, we have applied a scientific approach to derive appropriate targets for and beyond the year 2020. In the view of these findings, we consider it important for future research and according policy consultation to better consider strengths and weaknesses of sustainability assessments based on distance-to-target calculations, and also the impact of the selected reference values, targets defined and scoring systems applied on results and recommendations. One possibility to check and reveal the quality and robustness of assessment results could be to carry out sensitivity analyses to support decision-makers in becoming more aware how changes in reference values, distance-totarget calculations and targets can influence assessment results and policy recommendations.

As has been already discussed in [8], the SIS includes several new indicators addressing important sociotechnical aspects of the energy system and its transition that are not considered so far in the German monitoring report. This includes most of the indicators that are listed in Table 1 from the SI no. 32 to 45. For those indicators, only few data exist and it is not possible yet to create data series of at least 5 years. Since the distanceto-target method applied here requires such series, no assessment is possible for most of these indicators. Therefore, white traffic lights were assigned indicating the need to collect more comparable data over time. Since this is the case for 11 out of 45 indicators, it is difficult to assess the social and socio-economic impacts of the energy system and its transition, being the field of investigation that is the most exciting from our point of view. Among the indicators related to the sociotechnical interface, only one indicator is assigned with a green traffic light (SI no. 38), whereas three indicators (SI no. 32, 35 and 38) are assigned with a red traffic light. This indicates the need for action to close the gender pay gap in the energy sector and to increase public acceptance for renewable energies in the neighbourhood and also the volume of publicly funded loans for energy-related investments.
Considering the relatively big number of indicators included in the SIS may evoke the idea-most frequently expressed by decision-makers-to aggregate the single indicator assessment results to a 'sustainability index' for the energy system. The main argument behind this demand is to get a quick information that can be communicated more easily. However, there is no scientifically proven approach to sum up such heterogeneous indicators to generate a single sustainability score. Beyond that, an aggregated index would be of limited value for decision-makers, because recommendations for action have to address particular fields of action which can't be identified based on an aggregated index, but need disaggregated information provided in terms of specific indicators and targets. The assessment with the SIS presents such information in a transparent format. In any case, users of the SIS may select indicators according to the specific context they are acting in.

\section{Conclusions}

The developed Sustainability Indicator System (SIS) is a comprehensive tool to assess progress towards a more sustainable energy system and is, thus, useful to support decision-making. It includes new indicators to assess the socio-technical interface of the system that are lacking in existing indicators sets such as the German monitoring report 'Energy of the Future'. As for over one quarter of the SIS, no assessment is possible due to the lack of data series; research and monitoring is recommended to fill these gaps in order to carry out a really comprehensive sustainability assessment. As the distance-to-target methodology features some uncertainties and limitations that are associated with the method, it is crucial to check and display the quality and robustness of the assessment result by carrying out sensitivity analysis.

The SIS is considered a relevant contribution to sustainability research and practice for the further development of the energy transition. It can be used as a monitoring system by politics, administration, NGOs and society. As no other scientific approach provides a similar comprehensive tool for the sustainability assessment of energy systems, our work is a milestone that contributes both, to the academic discourse and the improvement of already existing indicator-based assessments such as the German monitoring report. However, both the determination of indicators and targets as well as the assessment methodology should be seen as a continuous process in which scientists, decision-makers, stakeholders and citizens should be integrated. In particular, target setting is a process, which is subject to social value patterns and thus needs political agreement and legitimation.

The SIS has the potential to provide information beyond the mere assessment of single indicators. For 
example, it is applicable to assess the impact on biodiversity in an indirect way and to identify trade-offs between sustainability issues. The assessment tool bears the potential for studying a wide range of questions concerning the future sustainability of the energy system. Besides, the SIS could be used to assess the sustainability of the energy system at different scales, at the state level as well as in other European countries if data series are available. With respect to the methodological challenges, applying the SIS for monitoring and decisionmaking in different contexts and at different scales would be beneficial to gain experiences about the adaptability of the SIS assessment tool and to get valuable clues how to elaborate our approach.

\section{Abbreviations}

BDI: Bundesverband der Deutschen Industrie; Cd: Cadmium; DTT: Distance-totarget; EEG: Erneuerbare-Energien-Gesetz; EPO: European Patent Office; Hg: Mercury; Pb: Lead; R\&D: Research and development; SAIDI: System Average Interruption Duration Index; SD: Sustainable development; SDGs: Sustainable development goals; SI: Sustainable indicator; SIS: Sustainable Indicator System; UK: United Kingdom; WGBU: Wissenschaftlicher Beirat der Bundesregierung Globale Veränderungen

\section{Acknowledgements}

The authors gratefully acknowledge financial support by the Helmholtz Alliance ENERGY-TRANS 'Future infrastructures for meeting energy demands - towards sustainability and social compatibility'.

For additional information, see https://www.energy-trans.de/

\section{Authors' contributions}

All authors designed the objectives and methods of the study and contributed to the development of the indicator system. CR prepared the manuscript with contributions from all co-authors. All authors read and approved the final manuscript.

\section{Consent for publication}

Not applicable.

\section{Competing interests}

The authors declare that they have no competing interests.

\section{Publisher's Note}

Springer Nature remains neutral with regard to jurisdictional claims in published maps and institutional affiliations.

Received: 17 August 2017 Accepted: 21 February 2018

Published online: 09 April 2018

\section{References}

1. World Commission on Environment and Development (WCED) (1987) Our common future. Oxford University Press, Oxford

2. United Nations (UN) (2016) The sustainable development goals report 2016. United Nations, New York

3. Bundesministerium für Wirtschaft und Energie (BMWi). 2012. Erster Monitoring-Bericht "Energie der Zukunft". https://www.bmwi.de/Redaktion/ DE/Publikationen/Energie/erster-monitoring-bericht-energie-der-zukunft. html. Accessed: 17 April 2017

4. Bundesministerium für Wirtschaft und Energie (BMWi). 2014. Zweiter Monitoring-Bericht "Energie der Zukunft". https://www.bmwi.de/Redaktion/ DE/Publikationen/Energie/zweiter-monitoring-bericht-energie-der-zukunft. html. Accessed 28 June 2016

5. Bundesministerium für Wirtschaft und Energie (BMWi). Ein gutes Stück Arbeit-Die Energie der Zukunft. https://www.bmwi.de/Redaktion/DE/ Publikationen/Energie/fortschrittsbericht.html. Accessed 20 Mar 2017
6. Bundesministerium für Wirtschaft und Energie (BMWi). 2015. Ein gutes Stück Arbeit-Die Energie der Zukunft. https://www.bmwi.de/Redaktion/DE/ Publikationen/Energie/vierter-monitoring-bericht-energie-der-zukunft.html. Accessed 20 Mar 2017

7. Federal Ministry for Economic Affairs and Energy (BMWi). 2016. Fifth monitoring report "the energy of the future" 2015. https://www.bmwi.de/Redaktion/EN/ Publikationen/monitoring-report-2016.html. Accessed 12 Apr 2017

8. Rösch C, Bräutigam K, Kopfmüller J, Stelzer V, Lichtner P (2017) Indicator system for the sustainability assessment of the German energy system and its transition. Energy, Sustainability and Society 7:1

9. Deutsches Zentrum für Luft- und Raumfahrt (DLR), Fraunhofer Institut für Windenergie und Energiesystemtechnik (IWES), Ingenieurbüro für neue Energien (IfnE). 2012. Langfristszenarien und Strategien für den Ausbau der erneuerbaren Energien in Deutschland bei Berücksichtigung der Entwicklung in Europa und global. http://www.dlr.de/dlr/Portaldata/1/Resources/bilder/ portal/portal_2012_1/leitstudie2011_bf.pdf. Accessed 10 Apr 2017

10. The Federal Government. Germany's national sustainable development strategy. https://www.bundesregierung.de/Content/EN/StatischeSeiten/ Schwerpunkte/Nachhaltigkeit/Anlagen/2017-06-20-langfassung-n-en.pdf? blob=publicationFile\&v=5. Accessed 25 Jan 2018

11. Statistisches Bundesamt (Destatis). 2017. Nachhaltige Entwicklung in Deutschland. https://www.destatis.de/DE/Publikationen/Thematisch/ UmweltoekonomischeGesamtrechnungen/Umweltindikatoren/ IndikatorenPDF_0230001.pdf?_blob=publicationFile. Accessed 25 Jan 2018

12. GWS, DIW, DLR, Prognos, ZSW. 2015. Beschäftigung durch erneuerbare Energien in Deutschland: Ausbau und Betrieb, heute und morgen. https:/www.zsw-bw.de/ uploads/media/Studie_Beschaeftigung_durch_EE_2015.pdf. Accessed 20 Mar 2017

13. GWS, Fraunhofer ISI, DIW Berlin, DLR, Prognos, ZSW. Bruttobeschäftigung durch erneuerbare Energien in Deutschland und verringerte fossile Brennstoffimporte durch erneuerbare Energien und Energieeffizienz. https:// www.bmwi.de/Redaktion/DE/Downloads/S-T/bruttobeschaeftigungerneuerbare-energien-monitioringbericht-2015.pdf?_blob= publicationFile\&v=11. Accessed 12 Apr 2017

14. Statistisches Bundesamt (Destatis). Number of employees 2006 to 2015. https://www.destatis.de/DE/ZahlenFakten/Indikatoren/ Konjunkturindikatoren/Arbeitsmarkt/karb811.html. Accessed 20 Mar 2017

15. Heindl, P. Measuring fuel poverty:general considerations and application to German household data. ftp://ftp.zew.de/pub/zew-docs/dp/dp13046.pdf. Accessed 20 Mar 2017

16. Tews, K. Energiearmut definieren, identifizieren und bekämpfen. http:// www.polsoz.fu-berlin.de/polwiss/forschung/systeme/ffu/aktuellepublikationen/13-tews-energiearmut/index.html. Accessed 25 Sept 2017

17. Statistisches Bundesamt (Destatis). Laufende WirtschaftsrechnungenEinnahmen und Ausgaben privater Haushalte 2012. https://www.destatis.de/ DE/Publikationen/Thematisch/EinkommenKonsumLebensbedingungen/ EinkommenVerbrauch/EinnahmenAusgabenprivaterHaushalte2150100127004. pdf? blob=publicationFile. Accessed 20 Mar 2017

18. Statistisches Bundesamt (Destatis) (2015) Wirtschaftsrechnungen: Einkommensund Verbrauchsstichprobe-Einnahmen und Ausgaben privater Haushalte für den Privaten Konsum, p 2013 https:/www.destatis.de/DE/Publikationen/Thematisch/ EinkommenKonsumLebensbedingungen/Konsumausgaben/EVS AufwendungprivaterHaushalte2152605139004.pdf?_blob=publicationFile. Accessed 20 Mar 2017

19. Statistisches Bundesamt (Destatis). Laufende WirtschaftsrechnungenEinkommen, Einnahmen und Ausgaben privater Haushalte 2014. https:// www.destatis.de/DE/Publikationen/Thematisch/

EinkommenKonsumLebensbedingungen/EinkommenVerbrauch/ EinnahmenAusgabenprivaterHaushalte2150100147004.pdf?_blob= publicationFile. Accessed 20 Mar 2017

20. Statistisches Bundesamt (Destatis). Laufende WirtschaftsrechnungenEinkommen, Einnahmen und Ausgaben privater Haushalte 2015. https:// www.destatis.de/DE/Publikationen/Thematisch/ EinkommenKonsumLebensbedingungen/EinkommenVerbrauch/ EinnahmenAusgabenprivaterHaushalte2150100157004.pdf? blob= publicationFile. Accessed 20 Mar 2017

21. Boardman B (1991) Fuel poverty. Belhaven Press, London

22. Pye, S.; Dobbins, A. 2015. Energy poverty and vulnerable consumers in the energy sector across the EU: analysis of policies and measures

23. Umweltbundesamt. 2017. Private Haushalte und Konsum. https://www. umweltbundesamt.de/daten/private-haushalte-konsum/energieverbrauchprivater-haushalte. Accessed 20 Mar 2017 
24. Statista. Anbaufläche von Energiepflanzen in Deutschland nach Art in den Jahren 2007 bis 2015 (in 1.000 Hektar). http://de.statista.com/statistik/daten/ studie/153072/umfrage/anbauflaeche-von-energiepflanzen-in-deutschlandnach-sorten-seit-2007/. Accessed 20 Mar 2017

25. Löschel, A.; Erdmann, G; Staiß, F.; Ziesing, H. Expertenkommission zum Monitoring-Prozess "Energie der Zukunft"-Stellungnahme zum vierten Monitoring-Bericht der Bundesregierung für das Berichtsjahr 2014. https:// www.bmwi.de/Redaktion/DE/Downloads/M-O/monitoringbericht-energieder-zukunft-stellungnahme-zusammenfassung-2014.pdf?_blob= publicationFile\&v=5. Accessed 20 Mar 2017

26. Wissenschaftlicher Beirat der Bundesregierung Globale Umweltveränderungen (WBGU). 2013. Welt im Wandel-Energiewende zur Nachhaltigkeit. http://www.wbgu.de/fileadmin/user_upload/wbgu.de/ templates/dateien/veroeffentlichungen/hauptgutachten/jg2003/wbgu_ jg2003.pdf. Accessed 12 Feb 2015

27. Lexas. Flächendaten aller Staaten der Erde. http://www.laenderdaten.de/ geographie/flaeche_staaten.aspx. Accessed 30 Nov 2016

28. Nagaoka S, Motohashi K, Goto A (2010) Patent statistics as an innovation indicator. In: Hall BH, Rosenberg $\mathrm{N}$ (eds) Handbook of the economics of innovation (Vol. 2), pp. 1083-1127.

29. Harhoff D, Scherer F (2000) Technology policy for a world of skewdistributed outcomes. Res Policy 29(4-5):559-566

30. Wuebker R, Wüstenhagen $\mathrm{R}$ (2011) The handbook of research on energy entrepreneurship. Edward Elgar, Cheltenham, UK, Northampton, MA

31. Farla J, Markard J, Raven R, Coenen L (2012) Sustainability transitions in the making: a closer look at actors, strategies and resources. Technol Forecast Soc Chang 79(6):991-998

32. Santos F, Eisenhardt K (2009) Constructing markets and shaping boundaries: entrepreneurial power in nascent fields. Acad Manag J 52(4):643-671

33. Borderstep Institut für Innovation und Nachhaltigkeit. 2015. Green economy Gründungsmonitor 2014-Grüne Wirtschaft als Gründungs- und Beschäftigungsmotor in Deutschland. http://www.borderstep.de/wpcontent/uploads/2015/05/Green_Economy_Gruendungsmonitor_20141.pdf. Accessed 20 Mar 2017

34. Zentrum für Europäische Wirtschaftsforschung (ZEW). 2014. Potenziale und Hemmnisse von Unternehmensgründungen im Vollzug der Energiewende. http://www.bmwi.de/DE/Mediathek/publikationen,did=639222.html. Accessed 20 Mar 2017

35. Helmers, C.; Schautschick, P.; Rogers, M. 2011. Intellectual property at the firm-level in the UK: the Oxford firm-level intellectual property database. https://www.economics.ox.ac.uk/department-of-economics-discussionpaper-series/intellectual-property-at-the-firm-level-in-the-uk-the-oxford-firmlevel-intellectual-property-database. Accessed 25 Jan 2018

36. Jaffe AB, Lerner J (2004) Innovation and its discontents how our broken patent system is endangering innovation and progress, and what to do about it. Princeton University Press

37. Bessen JE, Meurer MJ (2008) The private costs of patent litigation. SSRN Electronic Journal. http://www.bu.edu/law/workingpapers-archive/ documents/bessen-ford-meurer-no-11-45rev.pdf.

38. Graham S High technology entrepreneurs and the patent system: results of the 2008 Berkeley patent survey. Berkeley Technology Law Journal 24:255-327

39. Dehio, J., Engel, D.; Graskamp, R. 2006. Forschung und innovation: Wo steht Deutschland? Wirtschaftsdienst 86(8):517-523

40. Expertenkommission Forschung und Innovation (2012) Gutachten 2012. Technische Universität Berlin, Berlin

41. Statista. Ausgaben für Forschung und Entwicklung in Prozent des BIP in ausgewählten Ländern im Jahr 2013. https://de.statista.com/statistik/daten/ studie/158150/umfrage/ausgaben-fuer-forschung-und-entwicklung-2008/. Accessed 30 Mar 2016

42. Ministry of Family Affairs, Senior Citizens, Women and Youth (BMFSFJ). Pay inequality between women and men in Germany. https://www.bmfsfj.de/ blob/94442/efbd528467e361882848c23486fcc8d8/pay-inequality-data.pdf. Accessed 20 Mar 2017

43. Eurostat. 2017. Gender pay gap statistics. http://ec.europa.eu/eurostat/statisticsexplained/index.php/Gender_pay_gap_statistics. Accessed 20 Mar 2017

44. Statistisches Bundesamt (Destatis). Verdienste und Arbeitskosten. 2. 1. Arbeitnehmerverdienste 2007-2016. https://www.destatis.de/GPStatistik/ receive/DESerie_serie_00000297?list=all. Accessed 20 Mar 2017

45. Agentur für Erneuerbare Energien. Bundesländer in der Übersicht. http:// www.foederal-erneuerbar.de/uebersicht/bundeslaender/BW|BY|
B|BB|HB|HH|HE|MV|NI|NRW|RLP|SL|SN|ST|SH|TH|D/kategorie/akzeptanz/. Accessed 20 Mar 2017

46. Agentur für Erneuerbare Energien:. Umfrage 2013: Bürger befürworten Energiewende und sind bereit, die Kosten dafür zu tragen. http://www. unendlich-viel-energie.de/themen/akzeptanz2/akzeptanz-umfrage/umfrage2013-buerger-befuerworten-energiewende-und-sind-bereit-die-kostendafuer-zu-tragen. Accessed 20 Mar 2017

47. Agentur für Erneuerbare Energien. Umfrage Akzeptanz Erneuerbarer Energien 2014. http://www.unendlich-viel-energie.de/mediathek/grafiken/ akzeptanzumfrage-erneuerbare-energie-2014. Accessed 20 Mar 2017

48. Agentur für Erneuerbare Energien. Umfrage zur Akzeptanz Erneuerbarer Energien 2015. http://www.unendlich-viel-energie.de/mediathek/grafiken/ umfrage-akzeptanz-erneuerbare-energien-2015. Accessed 20 Mar 2017

49. Agentur für Erneuerbare Energien. Umfrage 2016: Bürger befürworten Energiewende und sind bereit, die Kosten dafür zu tragen. https://www. unendlich-viel-energie.de/mediathek/grafiken/akzeptanz-umfrage-2016. Accessed 20 Mar 2017

50. Umweltbundesamt. Daten zur Umwelt 2015. https://www. umweltbundesamt.de/sites/default/files/medien/376/publikationen/daten_ zur_umwelt_2015.pdf. Accessed 20 Mar 2017

51. Bundesfinanzministerium. Kassenmäßige Steuereinnahmen nach Steuerarten in den Kalenderjahren 2006-2009. http://www.bundesfinanzministerium.de/ Content/DE/Standardartikel/Themen/Steuern/Steuerschaetzungen_und_ Steuereinnahmen/2017-05-05-steuereinnahmen-nach-steuerarten-2010-2016. pdf?_blob=publicationFile\&v=5. Accessed 22 Mar 2017

52. Bundesfinanzministerium. Kassenmäßige Steuereinnahmen nach Steuerarten in den Kalenderjahren 2010-2015. http://www.bundesfinanzministerium.de/ Content/DE/Standardartikel/Themen/Steuern/Steuerschaetzungen_und_ Steuereinnahmen/2016-05-24-steuereinnahmen-nach-steuerarten-2010-2015. pdf?_blob=publicationFile\&v=4. Accessed 22 Mar 2017

53. Statista. Mauteinnahmen in Deutschland von 2005 bis 2015* (in Milliarden Euro). http://de.statista.com/statistik/daten/studie/75600/umfrage/ mauteinnahmen-in-deutschland-seit-2005/. Accessed 20 Mar 2017

54. Umweltbundesamt. 2013. Ökonomische Bewertung von Umweltschäden Methodenkonvention 2.0 zur Schätzung von Umweltkosten. https://www. umweltbundesamt.de/publikationen/oekonomische-bewertung-vonumweltschaeden-0. Accessed 20 Mar 2017

55. Klemisch H, Boddenberg M (2016) Energiegenossenschaften und Nachhaltigkeit. Aktuelle Tendenzen und soziologische Überlegungen. Soziologie und Nachhaltigkeit. Soziologie und Nachhaltigkeit - Beiträge zur sozial-ökologischen Transformationsforschung 2:6

56. Blome-Drees, J. 2012. Wirtschaftliche Nachhaltigkeit statt Shareholder Value. http://library.fes.de/pdf-files/wiso/08964.pdf. Accessed 25 Jan 2018

57. Elsen S (2014) Genossenschaften als transformative Kräfte auf dem Weg in die Postwachstumsgesellschaft. In: Genossenschaften und Klimaschutz. Akteure für eine zukunftsfähige Stadt. Springer VS, Wiesbaden

58. Deutscher Genossenschafts- und Raiffeisenverband e.V. (DGRV). 2015. Energiegenossenschaften. Ergebnisse der DGRV-Umfrage (zum 31.12.2015). https://www.dgrv.de/webde.nsf/7d5e59ec98e72442c1256e5200432395/ 418a5acd4479ba4ec1257e8400272bec/\$FILE/DGRV-Jahresumfrage.pdf. Accessed 10 Apr 2017

59. Deutscher Genossenschafts- und Raiffeisenverband e.V. (DGRV). Energiegenossenschaften. Ergebnisse der Umfrage des DGRV und seiner Mitgliedsverbände. Frühjahr 2013. https://www.dgrv.de/webde.nsf/ 7d5e59ec98e72442c1256e5200432395/dd9db514b5bce595c1257bb200263bbb/ \$FILE/Umfrageergebnisse\%20Energiegenossenschaften.pdf. Accessed 10 Apr 2017

60. Deutscher Genossenschafts- und Raiffeisenverband e.V. (DGRV). 2014. Energiegenossenschaften. Ergebnisse der Umfrage des DGRV und seiner Mitgliedsverbände. https:/www.dgrv.de/webde.nsf/ 7d5e59ec98e72442c1256e5200432395/418a5acd4479ba4ec1257e8400272bec/ \$FILE/DGRV-Jahresumfrage.pdf. Accessed 20 Mar 2017

61. Umweltbundesamt. 2014. Biodiversität. https://www.umweltbundesamt.de/ das-uba/was-wir-tun/forschen/umwelt-beobachten/biodiversitaet\#textpart-1. Accessed 29 Mar 2017

62. Umweltbundesamt. Critical loads für Schwermetalle. http://www. umweltbundesamt.de/themen/luft/wirkungen-von-luftschadstoffen/ wirkungen-auf-oekosysteme/critical-loads-fuer-schwermetalle\#textpart-1. Accessed 2 Aug 2017

63. Löschel, A.; Erdmann G; Staiß, F.; Ziesing, H. 2016. Expertenkommission zum Monitoring-Prozess, Energie der Zukunft" - Stellungnahme zum fünften Monitoring-Bericht der Bundesregierung für das Berichtsjahr 2015 
64. Council of European Energy Regulators. 2015. CEER benchmarking report 5. 2 on the continuity of electricity supply

65. Bundesministerium für Wirtschaft und Technologie, Bundesministerium für Umwelt, Naturschutz und Reaktorsicherheit. 2010. Energiekonzept für eine umweltschonende, zuverlässige und bezahlbare Energieversorgung. https:// www.bmwi.de/Redaktion/DE/Downloads/E/energiekonzept-2010.html. Accessed 19 Oct 2017

66. Zumach, A. Volksabstimmung in der Schweiz. Topverdiener werden nervös. taz

67. Umweltbundesamt. Strategien zur Emissionsminderung von

Luftschadstoffen. https://www.umweltbundesamt.de/daten/luftbelastung/ massnahmen-zur-emissionsminderung-von. Accessed 09 Nov 2017

68. Hirschl B, Heinbach K, Prahl A, Salecki S, Schröder A, Aretz A, Weiß J (Dezember 2015) Wertschöpfung durch erneuerbare Energien. Institut für ökologische Wirtschaftsforschung Berlin, Berlin

69. Prahl, A. 2014. Renewable energies' impact on value added and employment in Germany_-model results for 2012. Conference presentation

70. Lang, C. 2008. Marktmacht und Marktmachtmessung im deutschen Großhandelsmarkt für Strom. Gabler Verlag. s.l.

\section{Submit your manuscript to a SpringerOpen ${ }^{\circ}$ journal and benefit from:}

- Convenient online submission

- Rigorous peer review

- Open access: articles freely available online

- High visibility within the field

- Retaining the copyright to your article

Submit your next manuscript at $\gg$ springeropen.com 